\title{
Quantifying black carbon light absorption enhancement with a novel statistical approach
}

\author{
Cheng $\mathbf{W u}^{1,2}$, Dui $\mathrm{Wu}^{1,2,3}$, and Jian Zhen $\mathbf{Y u}^{4,5,6}$ \\ ${ }^{1}$ Institute of Mass Spectrometer and Atmospheric Environment, Jinan University, Guangzhou 510632, China \\ ${ }^{2}$ Guangdong Provincial Engineering Research Center for On-line Source Apportionment System of Air Pollution, \\ Guangzhou 510632, China \\ ${ }^{3}$ Institute of Tropical and Marine Meteorology, China Meteorological Administration, Guangzhou 510080, China \\ ${ }^{4}$ Division of Environment, Hong Kong University of Science and Technology, Clear Water Bay, Hong Kong, China \\ ${ }^{5}$ Atmospheric Research Centre, Fok Ying Tung Graduate School, Hong Kong University of Science and Technology, \\ Nansha, China \\ ${ }^{6}$ Department of Chemistry, Hong Kong University of Science and Technology, Clear Water Bay, Hong Kong, China
}

Correspondence: Cheng Wu (wucheng.vip@foxmail.com) and Jian Zhen Yu (jian.yu@ust.hk)

Received: 24 June 2017 - Discussion started: 20 July 2017

Revised: 27 November 2017 - Accepted: 28 November 2017 - Published: 11 January 2018

\begin{abstract}
Black carbon (BC) particles in the atmosphere can absorb more light when coated by non-absorbing or weakly absorbing materials during atmospheric aging, due to the lensing effect. In this study, the light absorption enhancement factor, $E_{\text {abs }}$, was quantified using a 1-year measurement of mass absorption efficiency (MAE) in the Pearl River Delta region (PRD). A new approach for calculating primary MAE $\left(\mathrm{MAE}_{\mathrm{p}}\right)$, the key for $E_{\mathrm{abs}}$ estimation, is demonstrated using the minimum $R$ squared (MRS) method, exploring the inherent source independency between BC and its coating materials. A unique feature of $E_{\text {abs }}$ estimation with the MRS approach is its insensitivity to systematic biases in elemental carbon (EC) and $\sigma_{\text {abs }}$ measurements. The annual average $E_{\text {abs550 }}$ is found to be $1.50 \pm 0.48$ ( \pm 1 SD) in the PRD region, exhibiting a clear seasonal pattern with higher values in summer and lower in winter. Elevated $E_{\mathrm{abs}}$ in the summertime is likely associated with aged air masses, predominantly of marine origin, along with long-range transport of biomassburning-influenced air masses from Southeast Asia. Coreshell Mie simulations along with measured $E_{\text {abs }}$ and absorption Ångström exponent (AAE) constraints suggest that in the PRD, the coating materials are unlikely to be dominated by brown carbon and the coating thickness is higher in the rainy season than in the dry season.
\end{abstract}

\section{Introduction}

Originating from incomplete combustion, black carbon (BC) is a crucial constituent of atmospheric aerosols, and is an air pollutant itself, having adverse health impacts on humans (Suglia et al., 2008). BC has also been recognized as the third-most important climate forcer due to its broad light absorbing capability across the UV-visible-IR spectrum (IPCC, 2013). BC can alter the climate in a variety of ways, including by direct forcing (Bond et al., 2011), affecting cloud cover (Koch and Del Genio, 2010) and precipitation (Tao et al., 2012), reducing the albedo of snow and ice (Hansen and Nazarenko, 2004) and causing surface dimming (Wild, 2011). The climate effects of BC can be global or regional (Ramanathan and Carmichael, 2008). A recent study found BC can modify planetary boundary layer meteorology, and thus enhance local pollution indirectly (Ding et al., 2016). However, due to its variable optical characteristics induced during atmospheric aging, large uncertainties still exist in estimating the radiative forcing from BC. Optical properties of $\mathrm{BC}$ can be predicted by knowing the mass concentration, mixing state and size distribution, which collectively serve as the cornerstone for modeling the climate effect of BC. In 3-D modeling studies, to conserve computational resources, the mass absorption efficiency (MAE) or mass absorption cross section (MAC) are widely used to convert black carbon mass concentration to light absorption co- 
efficient $\left(\sigma_{\mathrm{abs}}\right)$. MAE is a quantity which describes the light absorption ability per unit of elemental carbon (EC) mass:

$\operatorname{MAE}\left(\mathrm{m}^{2} \mathrm{~g}^{-1}\right)=\frac{\text { absorption coefficient } \sigma_{\mathrm{abs}}\left(\mathrm{Mm}^{-1}\right)}{\text { EC mass concentration }\left(\mu \mathrm{g} \mathrm{m}^{-3}\right)}$

As a fundamental input parameter, MAE has a critical impact on the $\mathrm{BC}$ radiative forcing estimation in climate modeling studies. Mixing state is one of the governing factors affecting MAE. Light absorption of soot particles is enhanced when coated with non-absorbing materials (Fuller et al., 1999) or weakly absorbing materials (Lack and Cappa, 2010) during atmospheric aging. The coating materials can focus more light onto the soot core through the lensing effect, resulting in elevated MAE (Wang et al., 2017). Strong correlations between MAE and the number/volume fraction of coated particles have been reported in urban areas like Tokyo (Naoe et al., 2009), Shenzhen (Lan et al., 2013) and Xi'an (Wang et al., 2014), implying that the elevated MAE observed at these locations was mainly due to the elevated fraction of coated soot particles. Total absorption $\left(\sigma_{\mathrm{abs}, \mathrm{t}}\right)$ of coated particles can be separated into two parts: primary absorption $\left(\sigma_{\mathrm{abs}, \mathrm{p}}\right)$ due to the uncoated soot core alone, and extra absorption $\left(\sigma_{\mathrm{abs}, \mathrm{c}}\right)$ due to lensing effect of the coating (Bond et al., 2006; Jacobson, 2006; F. Liu et al., 2016) and the presence of secondarily formed brown carbon $(\mathrm{BrC}$; Lack and Cappa, 2010; J. Liu et al., 2016).

$\sigma_{\mathrm{abs}, \mathrm{t}}=\sigma_{\mathrm{abs}, \mathrm{p}}+\sigma_{\mathrm{abs}, \mathrm{c}}$

The absorption enhancement factor $\left(E_{\mathrm{abs}}\right)$ then can be defined as ratio of the total absorption and primary absorption coefficients or the corresponding MAE values:

$E_{\mathrm{abs}}=\frac{\sigma_{\mathrm{abs}, \mathrm{t}}}{\sigma_{\mathrm{abs}, \mathrm{p}}}=\frac{\mathrm{MAE}_{\mathrm{t}}}{\mathrm{MAE}_{\mathrm{p}}}$,

where $\mathrm{MAE}_{\mathrm{p}}$ represents the ratio of $\sigma_{\mathrm{abs}, \mathrm{p}} / \mathrm{EC}$ for uncoated soot particles, similar to the concept of the primary OC / EC ratio in the EC tracer method:

$\mathrm{MAE}_{\mathrm{p}}=\frac{\sigma_{\mathrm{abs}, \mathrm{p}}}{\mathrm{EC}}$,

and the MAE of coated BC can be defined as follows:

$\mathrm{MAE}_{\mathrm{t}}=\frac{\sigma_{\mathrm{abs}, \mathrm{t}}}{\mathrm{EC}}$.

Thus, elevated MAE induced by coating during atmospheric aging results in an $E_{\text {abs }}$ larger than 1.

Previous model studies suggest that absorption by aged soot particles can be 1.5 times greater than fresh soot (Fuller et al., 1999; Bond et al., 2006). Laboratory studies have demonstrated that soot particles coated with secondary organic aerosol (SOA; Saathoff et al., 2003; Schnaiter et al., 2005; Tasoglou et al., 2017) and sulfuric acid (Zhang et al., 2008; Khalizov et al., 2009) can increase $E_{\text {abs }}$. An artificial coating experiment by Shiraiwa et al. (2010) found an
$E_{\text {abs }}$ of 2 for graphite particles growing in diameter from 185 to $370 \mathrm{~nm}$. A laboratory study by McMeeking et al. (2014) found that in the presence of $\mathrm{BrC}$, light absorption enhancement is more pronounced at the shorter wavelength. A recent chamber study coupling actual ambient air with seed BC particles implies that the timescale for $E_{\text {abs }}$ reaching 2.4 is only $5 \mathrm{~h}$ in Beijing but $18 \mathrm{~h}$ in Houston (Peng et al., 2016). Field studies conducted in recent years have also substantiated enhanced light absorption in Canada (Knox et al., 2009; Chan et al., 2011), USA (Lack et al., 2012b), UK (Liu et al., 2015) and Japan (Nakayama et al., 2014; Ueda et al., 2016). In contrast, field studies in California, USA (Cappa et al., 2012), found a weaker light absorption enhancement (6\% on average). A recent study suggests the mass ratio of non-BC content to $\mathrm{BC}$ particles determines the occurrence of the absorption enhancement of black carbon particles (Liu et al., 2017).

Two approaches are widely used to determine $E_{\text {abs }}$ from ambient measurements. The first approach removes the coating materials on particles physically using a thermodenuder (TD; Lack et al., 2012a) or by aerosol filter filtrationdissolution (AFD; X. Cui et al., 2016). The TD approach is briefly discussed here. Coating materials can be removed by TD at a working temperature of around 200 to $300^{\circ} \mathrm{C}$ (depending on the charring characteristics of aerosols at the sampling site) to measure $\sigma_{\mathrm{abs}, \mathrm{p}}$, which is cycled with measurements of $\sigma_{\mathrm{abs}, \mathrm{t}}$ (without passing through TD), allowing $E_{\text {abs }}$ to be obtained from the ratio of $\sigma_{\text {abs, }} / \sigma_{\text {abs, }}$ following Eq. (3). The major advantage of the TD approach is its ability to provide highly time-resolved measurements (minutes). A photoacoustic spectrometer (PAS) is commonly used with TD for detection to satisfy its high time resolution demands. As an in situ technique, PAS eliminates the artifacts associated with filter-based methods (Weingartner et al., 2003; Coen et al., 2010) and is often considered as the reference instrument for light absorption coefficient determination (Arnott et al., 2003, 2005). One limitation of the TD approach is that a universal optimal operation temperature does not exist, leading to a chemical-composition-dependent efficiency. If the temperature is too low, the coating cannot be fully removed, and charring can occur if the TD temperature is too high, leading to biased results. For example, a soot particle aerosol mass spectrometer (SP-AMS) study in Toronto found that the efficiency of BC coating removal by TD decreased substantially for wildfire-influenced samples (Healy et al., 2015). Another issue is particle loss due to TD, which can be $\sim 20 \%$ and needs to be taken into account (Ueda et al., 2016). It is also worth noting that $\mathrm{MAE}_{\mathrm{p}}$ from the TD approach is different from the $\mathrm{MAE}_{\mathrm{p}}$ at the emission source. First, the morphology of thermally denuded BC particles (compact aggregates) is different from that of freshly emitted BC particles (chain-like aggregates). Second, most of the coating is removed with the TD denuded soot particles, but freshly emitted soot particles usually come with a thin coating of organic carbon (OC) formed from condensation 
of $\mathrm{OC}$ vapors as the temperature drops from engine to the ambient air. As a result, the $\mathrm{MAE}_{\mathrm{p}}$ from the TD approach is expected to be lower than the $\mathrm{MAE}_{\mathrm{p}}$ of the emission source. In this sense, the TD approach may not be a prefect "time machine" to reverse the aging process for $E_{\mathrm{abs}}$ determination.

The second approach is the MAE ratio method, which is also stated in Eq. (3). The key to this method is determining an appropriate $\mathrm{MAE}_{\mathrm{p}}$ that can represent the MAE from primary emissions. One approach is to adopt the reference $\mathrm{MAE}_{\mathrm{p}}$ from the literature but it may fail to represent the actual $\mathrm{MAE}_{\mathrm{p}}$ at a specific sampling site, since $\mathrm{MAE}_{\mathrm{p}}$ varies temporally and spatially. For example, $\mathrm{MAE}_{\mathrm{p}}$ of diesel soot was found to be $7.1 \mathrm{~m}^{2} \mathrm{~g}^{-1}$ at $532 \mathrm{~nm}$ (Adler et al., 2010). A much higher $\operatorname{MAE}_{\mathrm{p}}\left(16 \mathrm{~m}^{2} \mathrm{~g}^{-1}\right.$ at $\left.530 \mathrm{~nm}\right)$ was observed from natural gas flaring (Weyant et al., 2016). $\mathrm{MAE}_{\mathrm{p}}$ of biomass burning (BB) samples is highly varied due to a wide range of fuel types and combustion conditions (Reid et al., 2005; Roden et al., 2006). A range from 6.1 to $80.8 \mathrm{~m}^{2} \mathrm{~g}^{-1}$ was reported for BB MAE $\mathrm{p}_{\mathrm{p}}$ at $550 \mathrm{~nm}$ (Pandey et al., 2016). Without the knowledge of source contributions, it is not feasible to derive a representative $\mathrm{MAE}_{\mathrm{p}}$ for $E_{\mathrm{abs}}$ estimation. The other commonly used approach is to determine $\mathrm{MAE}_{\mathrm{p}}$ from the dependency of MAE on the number fraction of coated soot particles measured by SP2 (Lan et al., 2013). Since MAE ( $y$ axis) is positively correlated with the number fraction of coated soot particles ( $x$ axis), $\mathrm{MAE}_{\mathrm{p}}$ can be determined by extending the regression line to $x=0$. It is worth noting that this approach provides only a rough approximation of $E_{\text {abs }}$ since the parameter used here (coated soot particles number fraction) ignores other main drivers of light absorption enhancement (e.g., coating thickness). As a result, this approach is only valid for a period of measurements for which coating thickness is relatively constant and in which MAE variations are dominated by the coated soot particle number fraction.

However, the high cost of the TD-PAS system and SP2 limits the field measurement of $E_{\mathrm{abs}}$ around the world. In addition, long-term $E_{\mathrm{abs}}$ measurements by a TD-PAS system and SP2 are not easily achieved and rarely reported. On the other hand, an Aethalometer and RT-ECOC analyzer can be effectively deployed for long-term measurements and $E_{\text {abs }}$ estimation, at a relatively lower cost. In this study, based on 1 year of hourly MAE measurements (with the field carbon analyzer and Aethalometer) at a suburban site in the Pearl River Delta (PRD) region of China, quantification of $\mathrm{MAE}_{\mathrm{p}}$ is demonstrated with a novel statistical approach, the minimum $R$ squared method (MRS; Wu and Yu, 2016). The aim of this study is to demonstrate the capability of $E_{\text {abs }}$ estimation using a 1-year data set with cost-effective instrumentation. The seasonal variability of MAE, absorption Ångström exponent (AAE) and $E_{\text {abs }}$ in the PRD region are characterized and their dependency on air mass origin and biomass burning are discussed. Abbreviations used in this study are summarized in Table 1 for quick reference.

\section{Ambient measurements}

Sampling was conducted from February 2012 to January 2013 at the suburban Nancun (NC) site $\left(23^{\circ} 0^{\prime} 11.82^{\prime \prime} \mathrm{N}\right.$, $\left.113^{\circ} 21^{\prime} 18.04^{\prime \prime} \mathrm{E}\right)$. Nancun, situated at the top of the highest peak (141 ma.s.1.) in Guangzhou's Panyu district, is located at the geographic center of the PRD region, making it a representative location for average atmospheric mixing characteristics of city clusters located there. Light absorption measurements were performed by a $7 \lambda$ Aethalometer (AE-31, Magee Scientific Company, Berkeley, CA, USA). The Aethalometer was equipped with a $2.5 \mu \mathrm{m}$ cyclone with a sampling flow rate of $4 \mathrm{~L} \mathrm{~min}^{-1}$. The Weingartner algorithm (Weingartner et al., 2003) was adopted to correct the sampling artifacts (aerosol loading, filter matrix and scattering effect) rooted in filter-based method. A customized Aethalometer data processing program $(\mathrm{Wu}, 2017 \mathrm{a})$ with graphical user interface was developed to perform data correction and detailed descriptions can be found in the Supplement (the program is available from https://sites.google.com/site/wuchengust). Details of the Aethalometer setup and data correction can be found in our previous paper (Wu et al., 2013).

EC mass concentrations were determined by a realtime ECOC analyzer (model RT-4, Sunset Laboratory Inc., Tigard, Oregon, USA). The sunset carbon analyzer sampled at hourly cycles at a flow rate of $8 \mathrm{~L} \mathrm{~min}^{-1}$ with a $\mathrm{PM}_{2.5}$ sharp-cut cyclone inlet. For each measurement hour, the first $45 \mathrm{~min}$ were for sample collection and the remaining $15 \mathrm{~min}$ for thermal-optical analysis. OC is volatized first by stepwise temperature ramping in an oxygen-free atmosphere while in the second stage EC is combusted in the presence of oxygen. Laser transmittance is applied to correct the charring artifact during the $\mathrm{OC}$ stage.

Considering a measurement precision of $5 \%$ for the Aethalometer (Hansen, 2005) and $24 \%$ for the RT-ECOC analyzer (Bauer et al., 2009), the propagated relative precision of $E_{\mathrm{abs}}\left(E_{\mathrm{abs}, \mathrm{Unc}}\right)$ is $35 \%$ following Eqs. (S1) and (S2) in the Supplement. It should be noted that $E_{\mathrm{abs}}$, Unc is mainly attributed to the measurement precision of EC of the RT-ECOC analyzer. Since the measurement precision of the RT-ECOC analyzer estimated by Bauer et al. (2009) is obtained from field measurements at an environment (EC below $1 \mu \mathrm{g} \mathrm{m}^{-3}$ ) where EC is much lower than the present study (annual average EC $2.66 \pm 2.27 \mathrm{\mu g} \mathrm{m}^{-3}$ ), the $E_{\text {abs, Unc }}$ of $35 \%$ should be considered as an upper limit for the present study.

Light scattering was measured by an integrating nephelometer (Aurora-1000, Ecotech, Melbourne, Australia). Water-soluble ions were measured by the Monitor for AeRosol and Gases (MARGA; ten Brink et al., 2007). Both instruments are equipped with a $\mathrm{PM}_{2.5}$ inlet to remove the coarse particles 
Table 1. Abbreviations.

\begin{tabular}{ll}
\hline Abbreviation & Definition \\
\hline AAE $470-660$ & absorption Angström exponent between 470 and $660 \mathrm{~nm}$ \\
BB & biomass burning \\
BrC & brown carbon \\
$D_{\text {core }}, D_{\text {shell }}$ & particle diameter of core/shell \\
$E_{\text {abs550 }}$ & light absorption enhancement factor at $550 \mathrm{~nm}$ \\
$\sigma_{\text {abs550 }}$ & light absorption coefficient at $550 \mathrm{~nm}$ \\
$\sigma_{\text {abs, }}$ & total light absorption coefficient of a coated particle \\
$\sigma_{\text {abs, }}$ & primary light absorption coefficient attributed to the soot core alone of a coated particle \\
$\sigma_{\text {abs, c }}$ & extra light absorption other than $\sigma_{\text {abs, }}$, including those from the lensing effect of coating \\
& on the soot core and brown carbon \\
LII & laser-induced incandescence technique for soot measurement \\
MAE 550 & mass absorption efficiency at $550 \mathrm{~nm}$, also known as mass absorption cross section (MAC) \\
MAE, 550 & primary MAE of freshly emitted soot particles at 550 nm \\
MAAP & multi-angle absorption photometer \\
MOUDI & micro-orifice uniform deposit impactor \\
MRS & minimum $R$ squared method \\
PAS & photoacoustic spectrometer \\
PRD & Pearl River Delta region, China \\
SP2 & single-particle soot photometer \\
SSA & single-scattering albedo \\
TD & thermodenuder \\
TOA & thermal-optical analysis \\
TSV & total spatial variance in backward trajectories cluster analysis \\
\hline
\end{tabular}

\subsection{Uncertainties of MAE determination}

Two major uncertainties associated with the $\sigma_{\mathrm{abs}}$ and EC determination techniques should be taken into account when comparing MAE across different studies. For the $\sigma_{\text {abs }}$ determination technique, photoacoustic spectroscopy (PAS) is an in situ technique free from filter-based artifacts, but its application is limited by its high cost. The filter-based optical transmittance method (e.g., Aethalometer and multi-angle absorption photometer, MAAP) is the most widely used technique around the world, but data correction is needed to minimize the bias from artifacts due to the loading, matrix and scattering effects (Weingartner et al., 2003; Arnott et al., 2005; Schmid et al., 2006; Virkkula et al., 2007; Coen et al., 2010; Drinovec et al., 2017; Saturno et al., 2017). Besides these artifacts, RH is also a source of $\sigma_{\text {abs }}$ measurement uncertainty. Elevated RH is not only a driving force of increased $\sigma_{\mathrm{abs}}$ due to the hygroscopic growth of particles but also a factor affecting ambient $\sigma_{\text {abs }}$ measurements. Previous studies found $\sigma_{\mathrm{abs}}$ from PAS exhibit a systematic decrease when RH $>70 \%$ (Arnott et al., 2003; Kozlov et al., 2011). Water evaporation was found as the major cause for the biased PAS $\sigma_{\text {abs }}$ measurements under high RH (Raspet et al., 2003; Lewis et al., 2009b; Langridge et al., 2013). Filter-based measurements are also affected under high RH conditions. For example, Arnott et al. (2003) observed erratic responses from a particle soot absorption photometer (PSAP) as RH changed. The main reason is traced to the hydrophilic cellulose mem- brane, which serves to reinforce the quartz filter used in the PSAP. The fibers can swell and shrink as RH changes, causing unwanted light attenuation signal. The PTFE-coated fiberglass tape has been available since 2012 for recent model of Aethalometers to minimize RH interference (Magee Scientific, 2017). A study by Schmid et al. (2006) reported dependency of the PSAP $\sigma_{\mathrm{abs}}$ on RH, but found negligible effect of RH on Aethalometer performance. It is also worth noting that $\mathrm{RH}$ in the Aethalometer optical chamber may be lower than the ambient RH due to the slightly elevated temperature inside the instrument. The magnitude of $\mathrm{RH}$ difference was found to be similar between different instruments: $20 \%$ for the Aethalometer (Schmid et al., 2006) and $15 \%$ for the nephelometer (Guyon et al., 2004). The RH in the Aethalometer optical chamber was not measured in this study. We expected its level to be slightly lower than the ambient RH. Cappa et al. (2008) found $\sigma_{\text {abs }}$ measurements from PSAP and PAS maintained a high linearity even under high RH conditions (65-91\%). Inter-comparison studies demonstrated that with proper corrections, Aethalometer $\sigma_{\mathrm{abs}}$ measurements agree well with those from PAS (Ajtai et al., 2011). During the inter-comparison study of an Aethalometer (AE-16) and a PAS in Guangzhou (Wu et al., 2009), good correlation was found $\left(R^{2}=0.96\right)$ as shown in Fig. S1 in the Supplement. These comparison results imply that the Aethalometer results are linearly correlated with PAS measurements and RH has a limited interference on Aethalometer measurements. In our study, careful corrective measures 
(Wu et al., 2013) are conducted for the Aethalometer $\sigma_{\text {abs }}$ data treatment to minimize these artifacts, but they still cannot be fully eliminated.

For the EC determination, different thermal-optical analysis (TOA) protocols can impact the measurement variability and thus MAE. As shown in Table S1, MAE for the same samples at Fresno varied from 6.1 to $9.3 \mathrm{~m}^{2} \mathrm{~g}^{-1}$, depending on which EC analysis protocol was applied (Chow et al., 2009). Studies in the PRD found that discrepancies in EC measured by different analysis protocols could be as large as a factor of 5 (C. Wu et al., 2012, 2016), which adds to the uncertainty for the MAE estimation. In addition, EC from TOA is also different from refractory $\mathrm{BC}(\mathrm{rBC})$ reported by the laser-induced incandescence (LII) technique (e.g., singleparticle soot photometer, SP2). For example, two studies in Toronto (Knox et al., 2009; Chan et al., 2011) both used the PAS for $\sigma_{\mathrm{abs}}$ measurement but different techniques for EC mass determination, resulting in very different MAE results. LII instruments are usually calibrated with a commercially available surrogate (e.g., fullerene) since direct calibration with ambient soot is not easy to achieve. Laborde et al. (2012) indicates that the incandescence response of SP2 exhibits a dependency on soot type (15\% between fullerene and denuded diesel soot particles; $14 \%$ between biomass burning and denuded diesel soot particles). Due to the absence of widely accepted reference materials for EC, the uncertainties in EC determination will exist in the foreseeable future. All these uncertainties, including the uncertainty of $\mathrm{rBC}$ mass determination from SP2, uncertainty of EC in TOA, the discrepancy between SP2 rBC and TOA EC and the discrepancy of $\sigma_{\mathrm{abs}}$ between filter transmission and photoacoustic methods, can contribute to the differences in MAE listed in Table $\mathrm{S} 1$.

Systematic bias in MAE (e.g., overestimation of $\sigma_{\text {abs }}$ and variability of EC mass with different TOA protocols) discussed above have little effect on $E_{\text {abs }}$ estimation with MRS. As shown in Eq. (3), $E_{\mathrm{abs}}$ is the ratio of $\mathrm{MAE}_{\mathrm{t}}$ to $\mathrm{MAE}_{\mathrm{p}}$ or $\sigma_{\mathrm{abs}, \mathrm{t}}$ to $\sigma_{\mathrm{abs}, \mathrm{p}}$; thus most of the bias in EC mass or $\sigma_{\mathrm{abs}}$ is canceled out during the $E_{\text {abs }}$ calculation. More details are discussed in Sect. 5.1.

\section{Methodology}

\subsection{MAE $_{p}$ estimation with MRS from the ambient data}

In this section, a new approach for $\mathrm{MAE}_{\mathrm{p}}$ estimation is introduced for $E_{\text {abs }}$ determination, which requires knowledge of differentiating $\sigma_{\mathrm{abs}, \mathrm{p}}$ and $\sigma_{\mathrm{abs}}$, c portions in $\sigma_{\mathrm{abs}, \mathrm{t}}$. The idea of decoupling $\sigma_{\mathrm{abs}}$ into $\sigma_{\mathrm{abs}, \mathrm{p}}$ and $\sigma_{\mathrm{abs}, \mathrm{c}}$ is conceptually similar to decoupling OC into primary OC (POC) and secondary OC (SOC) in the EC tracer method as shown in Table 2. In the EC tracer method, if $(\mathrm{OC} / \mathrm{EC})_{\mathrm{p}}$ is known, POC can be determined from OC (Turpin and Huntzicker, 1991). The role of $\mathrm{MAE}_{\mathrm{p}}$ here is similar to the role of $(\mathrm{OC} / \mathrm{EC})_{\mathrm{p}}$, the pri- mary OC / EC ratio in the EC tracer method (a comparison is given in Table 2). If $\mathrm{MAE}_{\mathrm{p}}$ (average MAE from primary emission sources) is known, $E_{\text {abs }}$ can be obtained from the ratio of $\mathrm{MAE}_{\mathrm{t}} / \mathrm{MAE}_{\mathrm{p}}$ (Eq. 3). Therefore, the key for $E_{\mathrm{abs}}$ estimation is to derive an appropriate $\mathrm{MAE}_{\mathrm{p}}$. It is worth noting that $\mathrm{MAE}_{\mathrm{p}}$ here does not represent MAE from a single or specific primary emission source; instead, it reflects an average and effective MAE that has taken consideration of various primary emission sources. Thus, the $\mathrm{MAE}_{\mathrm{p}}$ is conceptually analogous to $(\mathrm{OC} / \mathrm{EC})_{\mathrm{p}}$ in the $\mathrm{EC}$ tracer method in which the primary ratio reflects an overall ratio from primary emission sources rather than from a single primary source.

The minimum $R$ squared method (MRS) explores the inherent independency between pollutants from primary emissions (e.g., EC) and products associated with secondary formation processes (e.g., SOC, $\sigma_{\mathrm{abs}, \mathrm{c}}$ ) to derive the primary ratios (e.g., $\left.(\mathrm{OC} / \mathrm{EC})_{\mathrm{p}}, \mathrm{MAE}_{\mathrm{p}}\right)$ in the EC tracer method (Wu and $\mathrm{Yu}, 2016)$. When applying MRS for light absorption enhancement estimation, MRS is used to explore the inherent independency between EC and $\sigma_{\mathrm{abs}}$, , which is gained during atmospheric aging after emission. An example of $\mathrm{MAE}_{\mathrm{p}}$ estimation with MRS is shown in Fig. 1. Firstly, the assumed $\mathrm{MAE}_{\mathrm{p}}$ value is varied continuously over a reasonable range (0.01 to $50 \mathrm{~m}^{2} \mathrm{~g}^{-1}$ as shown in Fig. 1). Then at each hypothetical MAE $\mathrm{M}_{\mathrm{p}}, \sigma_{\mathrm{abs}, \mathrm{c}}$ can be calculated by Eq. (6) (a combination of Eqs. 2 and 4) using EC and $\sigma_{\mathrm{abs}, \mathrm{t}}$ from ambient measurements.

$\sigma_{\mathrm{abs}, \mathrm{c}}=\sigma_{\mathrm{abs}, \mathrm{t}}-\mathrm{MAE}_{\mathrm{p}} \times \mathrm{EC}$

Accordingly, for each hypothetical $\mathrm{MAE}_{\mathrm{p}}$, a correlation coefficient value $\left(R^{2}\right)$ of $\sigma_{\mathrm{abs}, \mathrm{c}}$ vs. EC (i.e., $\left.R^{2}\left(\sigma_{\mathrm{abs}, \mathrm{c}}, \mathrm{EC}\right)\right)$ can be obtained. The series of $R^{2}$ ( $\left.\sigma_{\mathrm{abs}, \mathrm{c}}, \mathrm{EC}\right)$ values ( $y$ axis) are then plotted against the assumed $\mathrm{MAE}_{\mathrm{p}}$ values ( $x$ axis) as shown by the red curve in Fig. 1. The physical meaning of this plot can be interpreted as follows. The $\sigma_{\mathrm{abs}, \mathrm{p}}$ is the fraction of light absorption due to primary emitted soot particles. As a result, $\sigma_{\mathrm{abs}, \mathrm{p}}$ is well correlated with EC mass. In contrast, the $\sigma_{\mathrm{abs}, \mathrm{c}}$ is the fraction of light absorption gained by the lensing effect of the coating on particles after emission. The variability of $\sigma_{\mathrm{abs}}$ c mainly depends on the coating thickness of the soot particles. Consequently, $\sigma_{\mathrm{abs}} \mathrm{c}$ is independent of EC mass. Since variations of EC and $\sigma_{\mathrm{abs}, \mathrm{c}}$ are independent, the assumed $\mathrm{MAE}_{\mathrm{p}}$ corresponding to the minimum $R^{2}$ $\left(\mathrm{EC}, \sigma_{\mathrm{abs}, \mathrm{c}}\right.$ ) would then represent the most statistically probable $\mathrm{MAE}_{\mathrm{p}}$ of the tested data set.

A computer program (Wu, 2017b) in Igor Pro (WaveMetrics, Inc. Lake Oswego, OR, USA) was developed to facilitate MRS calculation with a user friendly graphical user interface. Another two Igor Pro-based computer programs, Histbox (Wu, 2017c) and Scatter Plot (Wu, 2017d), are used for generating the histograms, box plots and scatter plots (with Deming regressions) presented in this study. Detailed descriptions of these computer programs can be found in the Supplement and the computer programs are available from https://sites.google.com/site/wuchengust. 
Table 2. Comparison of MRS application on $(\mathrm{OC} / \mathrm{EC})_{\mathrm{p}}$ (for SOC estimation) and MAE $\mathrm{p}_{\mathrm{p}}$ (for $E_{\mathrm{abs}}$ estimation).

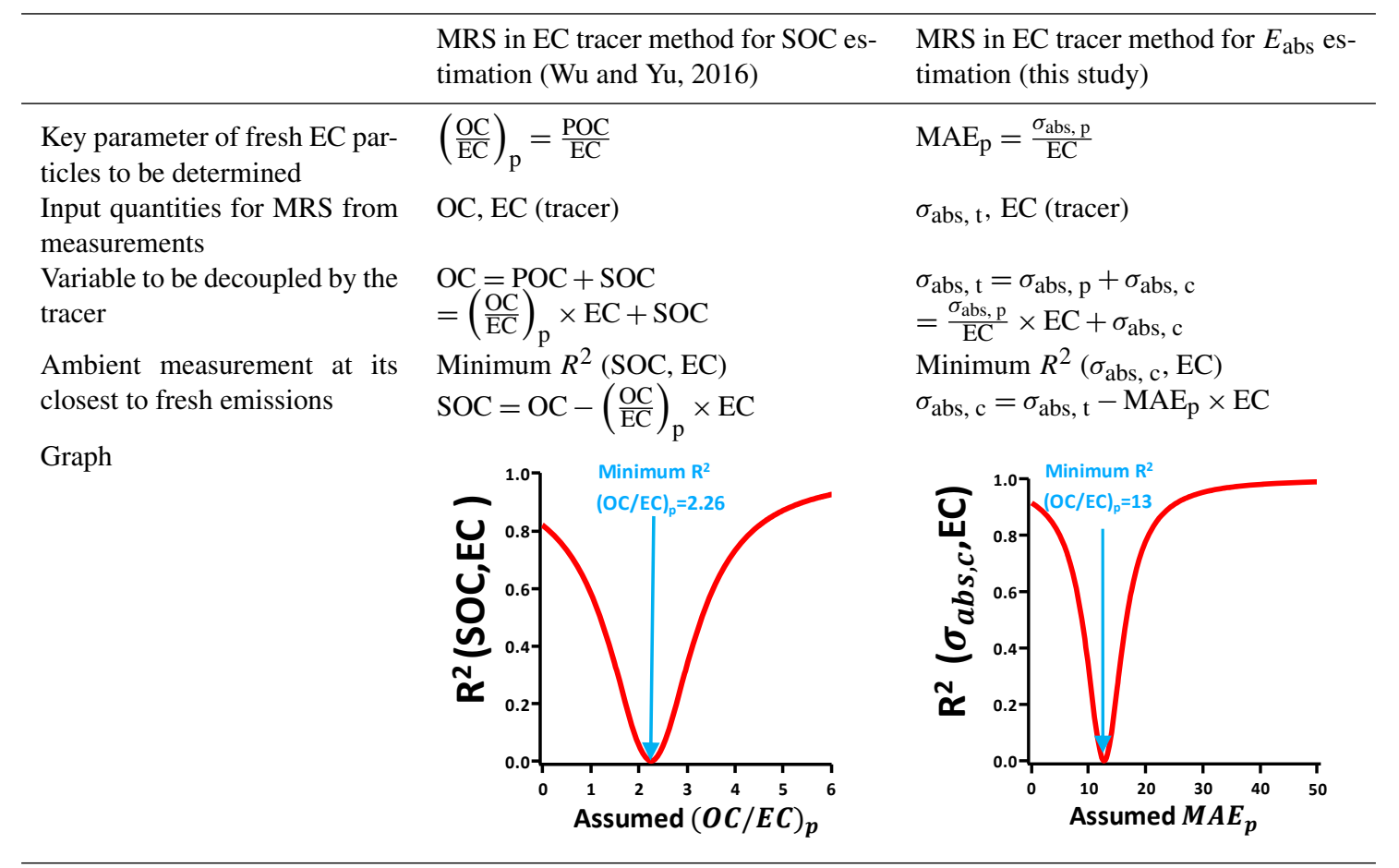

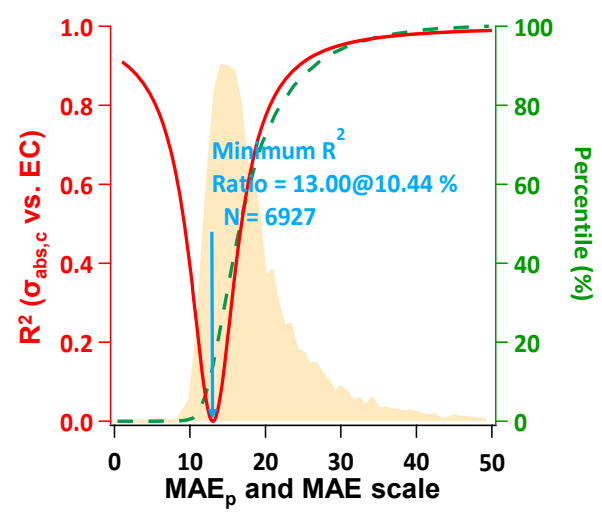

Figure 1. Minimum $R$ squared (MRS) plot for calculating $\mathrm{MAE}_{\mathrm{p}}$ at $550 \mathrm{~nm}$. The red curve is the correlation result between $\sigma_{\mathrm{abs}} \mathrm{c}$ $\left(\sigma_{\mathrm{abs}, \mathrm{t}}-\mathrm{EC} \times \mathrm{MAE}_{\mathrm{p}}\right)$ and EC mass. The shaded area in light tan represents the frequency distribution of observed MAE. The dashed green line is the cumulative distribution of observed MAE.

\subsection{Mie simulation}

It can be informative to model a single soot particle using Mie theory (Bohren and Huffman, 1983) and understand the theoretical range and variability of the soot particle's optical properties. Three mixing states are widely employed for parameterization: internal, external and core-shell mixing. To better represent reality (coating due to the aging process), a core-shell model is considered in the Mie calcula- tion (Fig. S2), which is more realistic than a volume mixture model (Bond et al., 2006). An aerosol optical closure study in the North China Plain (NCP) found that the coreshell model can provide better performance than assuming purely internal mixing and external mixing (Ma et al., 2012). A morphology study using Scanning transmission X-ray microscopy found that core-shell is the dominating mixing state in ambient samples (Moffet et al., 2016). It should be noted that the core-shell model assumption still has its own limitations. A single-particle soot photometer (SP2) study by Sedlacek et al. (2012) reported a negative lag time between the scattering and incandescence signals in samples influenced by biomass burning, implying a near-surface location of soot relative to non-absorbing materials. Near-surface mixing of soot has also been observed in Tokyo, but accounted for only $10 \%$ of total mixed soot containing particles (Moteki et al., 2014). Considering the domination of core-shell-type particles in the ambient environment, the core-shell assumption in our optical model is sufficient to approximate reality.

As shown in Fig. S2, freshly emitted soot particles are chain-like aggregates of small spheres $(\sim 30-50 \mathrm{~nm})$. After the aging process, soot particles are coated with organic and inorganic materials. Sufficient evidence has shown that the coating not only results in particle size growth but also makes the soot core become more compact due to its collapse (Alexander et al., 2008; Zhang et al., 2008; Lewis et al., 2009a), especially under high RH conditions (Leung et al., 2017). A recent study by Pei et al. (2017) shown that fill- 
ing of void space within the agglomerate is the first step of the morphological transformation of soot particles in atmospheric aging, leading to a spherical soot core. Since the spherical core and shell favor Mie simulation, both core and shell are considered as spheres in the Mie calculation.

To investigate the spectrum properties of soot particles, 11 wavelengths $(370,405,470,520,532,550,590,660$, 781,880 and $950 \mathrm{~nm}$ ) are considered in calculations to cover wavelengths in the most frequently used absorption measurement instruments. A refractive index (RI) of 1.85-0.71 is adopted for soot core (Bond and Bergstrom, 2006) and 1.55 for non-absorbing coating (clear shell) in the Mie calculation for all wavelengths. Studies suggest a group of organic matter $(\mathrm{OM})$, known as brown carbon $(\mathrm{BrC})$, can absorb solar radiation at UV wavelengths (Kirchstetter et al., 2004). Thus, a BrC coating (brown shell) scenario is also considered in Mie simulations following the wavelengthdependent RI suggested by Lack and Cappa (2010), which ranges from $1.55-0.059 \mathrm{i}(370 \mathrm{~nm})$ to $1.55-0.0005 \mathrm{i}(950 \mathrm{~nm})$. A modeling study by Bond et al. (2006) indicates that absorption amplification is not sensitive to the RI; thus the result below is not expected to be sensitive to the RI variability. Due to the spherical assumption of the $\mathrm{BC}$ core, a constant particle density is adopted for simplicity instead of size-dependent particle density. But it is worth noting that in reality, the effective density of soot varies with particle size due to the morphology change during particle aging (Tavakoli and Olfert, 2014; Dastanpour et al., 2017). Both core diameters $\left(D_{\text {core }}\right)$ and shell diameters $\left(D_{\text {shell }}\right)$ are constrained in the range of $\sim 10-3000 \mathrm{~nm}$ in the model simulations. The Mie calculations are implemented with a customized program (Wu, 2017e) written in Igro Pro (WaveMetrics, Inc. Lake Oswego, OR, USA) and it is available from https://sites.google.com/site/wuchengust. It should be noted that the core-shell-type mixing state of particles is still rare in 3-D atmospheric models like WRF-Chem (Matsui et al., 2013; Nordmann et al., 2014) due to computational cost limitation.

\subsubsection{Mie-modeled absorption Ångström exponent (AAE)}

The absorption Ångström exponent (AAE) is a widely used parameter that describes the wavelength dependence of aerosol light absorption (Moosmuller et al., 2011), which can be written explicitly as

$\operatorname{AAE}\left(\lambda_{1}, \lambda_{2}\right)=-\frac{\ln \left(\sigma_{\mathrm{abs}, \lambda 1}\right)-\ln \left(\sigma_{\mathrm{abs}, \lambda 2}\right)}{\ln \left(\lambda_{1}\right)-\ln \left(\lambda_{2}\right)}$.

It is well known that ambient soot particles exhibit an AAE close to unity (Bond, 2001). Modeled variability in $\mathrm{AAE}_{470-660}$ of bare soot particles is shown in Fig. S3. For soot particles with $D_{\text {core }}<200 \mathrm{~nm}, \mathrm{AAE}_{470-660}$ is very close to 1 and decreases significantly for particles with $D_{\text {core }}>200 \mathrm{~nm}$. Considering a typical $D_{\text {core }}$ of freshly emit- ted soot particles smaller than $200 \mathrm{~nm}$ (Rose et al., 2006; China et al., 2013), the model results confirm the frequently observed AAE close to 1 from ambient measurements (Kirchstetter et al., 2004). Modeled variability in AAE $470-660$ of soot particles coated by non-absorbing substances (clear shell) and weakly absorbing materials (brown shell) is shown in Fig. 2. An absorption Angström exponent value elevated to $\sim 2$ is observed in the clear shell scenario (Fig. 2a and b) for the most probable soot core particle sizes $(<200 \mathrm{~nm})$, which agrees well with a previous model study (Lack and Cappa, 2010), implying that elevated AAE cannot be exclusively attributed to mixing with $\mathrm{BrC}$. AAE elevation is more pronounced in the brown shell scenario. For soot particles with $D_{\text {core }}<200 \mathrm{~nm}$, brown shell AAE $470-660$ can easily reach 3 for a coating of $D_{\text {shell }} / D_{\text {core }}=3$ (Fig. $2 \mathrm{c}$ and d). These high AAE results are consistent with the previous model study (Lack and Cappa, 2010) and could partially explain the high AAE observed in measurement studies (Kirchstetter et al., 2004; Hoffer et al., 2006), since the presence of externally mixed $\mathrm{BrC}$ particles also contribute to the wavelength-dependent light absorption.

\subsubsection{Mie-modeled single-scattering albedo (SSA)}

Variability in modeled $\mathrm{SSA}_{525}$ of soot particles coated by non-absorbing substances and weakly absorbing materials (e.g., $\mathrm{BrC}$ ) is shown in Fig. S4. For particles with $D_{\text {core }}<$ $200 \mathrm{~nm}$ and $D_{\text {shell }} / D_{\text {core }}<3$, the SSA increases gradually (up to $\sim 0.9$ ) with a thicker coating and behaves similarly in clear shell and brown shell scenarios.

\subsubsection{Mie-modeled mass absorption efficiency (MAE)}

MAE is a useful indicator for soot mixing state. Variability in MAE of bare soot particles as a function of particle size at a wavelength of $550 \mathrm{~nm}$ is illustrated in Fig. S5. The magnitude of MAE is sensitive to the soot density assumption, especially for particles $<200 \mathrm{~nm}$ (Fig. S5), but the overall trend of particle size dependency is similar among different density scenarios. MAE peaks at a particle size of $200 \mathrm{~nm}$ and decreases dramatically for larger particles. In our MAE calculation, a soot density of $1.9 \mathrm{~g} \mathrm{~cm}^{-3}$ is adopted, as suggested by Bond and Bergstrom (2006). The purpose of adopting constant density is to simplify the MAE calculation. It should be noted that the effective density of soot core is highly variable in ambient environments. For example, a study in Beijing (Y. Zhang et al., 2016) found a value of $1.2 \mathrm{~g} \mathrm{~cm}^{-3}$. A recent chamber study found the effective density of soot can evolve from 0.43 to $1.45 \mathrm{~g} \mathrm{~cm}^{-3}$ during aging as coated by $m$-Xylene oxidation products (Guo et al., 2016). A study using a single-particle aerosol mass spectrometer in Guangzhou found the effective density of soot increased with particle size in the range of 400 to $1600 \mathrm{~nm}$ (G. Zhang et al., 2016). The MAE of coated particles from different core/shell diameter combinations are shown in Fig. S6. For 

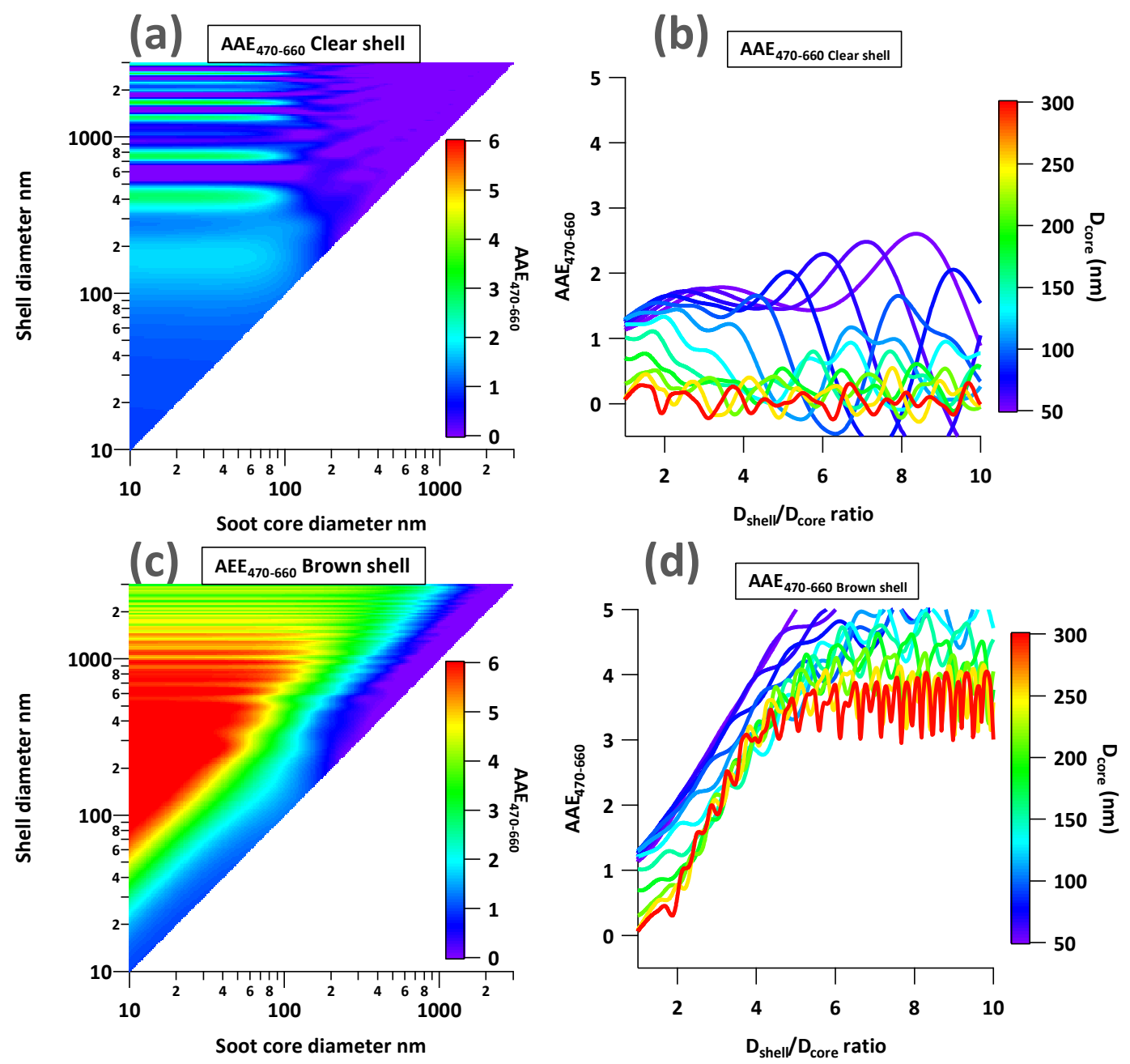

Figure 2. Mie simulated size dependency of $\mathrm{AAE}_{470-660}$ soot particles. (a) Combination of different clear shell ( $y$ axis) and core diameters ( $x$ axis). The color coding represents the $\mathrm{AAE}_{470-660}$ of a particle with specific core and clear shell size; (b) cross-section views of (a). The color coding represents different $D_{\text {core }}$ in the range of $\sim 50-300 \mathrm{~nm}$. (c, d) Similar to panels (a) and (b) but for the brown shell scenario.

thickly coated particles, the MAE in the clear shell scenario varied as $D_{\text {shell }} / D_{\text {core }}$ increased, but the MAE of brown shell scenario increased quasi-monotonously with $D_{\text {shell }} / D_{\text {core }}$.

\subsubsection{Mie-modeled light absorption enhancement factor $\left(E_{\text {abs }}\right)$}

$E_{\text {abs }}$ is a better indicator for soot mixing state than MAE since it does not rely on the soot density assumption and is more suitable for comparison of Mie simulations with ambient measurements. Modeled variability in $E_{\text {abs }}$ of soot particles coated by non-absorbing substances and weakly absorbing materials (e.g., BrC) is shown in Fig. $3 \mathrm{a}$ and c, respectively. $E_{\text {abs }}$ is not only sensitive to the core/shell diameter combination, but it also behaves very differently with the clear and brown shell assumptions. For the clear shell scenario, when $D_{\text {coat }} / D_{\text {core }}<2, E_{\text {abs }}$ does not exceed 2 for particles with different soot core sizes, but with the same
$D_{\text {coat }} / D_{\text {core }}$, a larger soot core size yields a higher $E_{\text {abs }}$ (Fig. 3b, cross sections of Fig. 3a). If $D_{\text {coat }} / D_{\text {core }}>2, E_{\text {abs }}$ could be 3 to 5 for particles with $D_{\text {core }}>200 \mathrm{~nm}$, but for particles with a soot core larger than $200 \mathrm{~nm}$, the $E_{\text {abs }}$ would be limited to $\sim 2$ as shown in Fig. 3b. For the brown shell scenario, $E_{\text {abs }}$ increased quasi-monotonically with $D_{\text {coat }} / D_{\text {core }}$, and this trend is similar for different soot core sizes (Fig. 3d). The main reason is that in the brown shell scenario, both lensing effect and $\mathrm{BrC}$ absorption contribute to $E_{\text {abs. }}$. As shown in Fig. S7, the BrC absorption contribution to total $E_{\text {abs }}$ strongly depends on coating thickness and is insensitive to soot core diameters. When the coating is relatively thin $(<5 \mathrm{~nm}$ for $\lambda$ at $370 \mathrm{~nm},<15 \mathrm{~nm}$ for $\lambda$ at $550 \mathrm{~nm}$ and $<40 \mathrm{~nm}$ for $\lambda$ at $880 \mathrm{~nm}$ ), BrC absorption contribution to the total $E_{\text {abs }}$ is less than $20 \%$. As the coating increases to a certain level ( $\sim 15 \mathrm{~nm}$ for $\lambda$ at $370 \mathrm{~nm}, \sim 35 \mathrm{~nm}$ for $\lambda$ at $550 \mathrm{~nm}$ and $\sim 90 \mathrm{~nm}$ for $\lambda$ at $880 \mathrm{~nm}$ ), BrC absorption contribution 

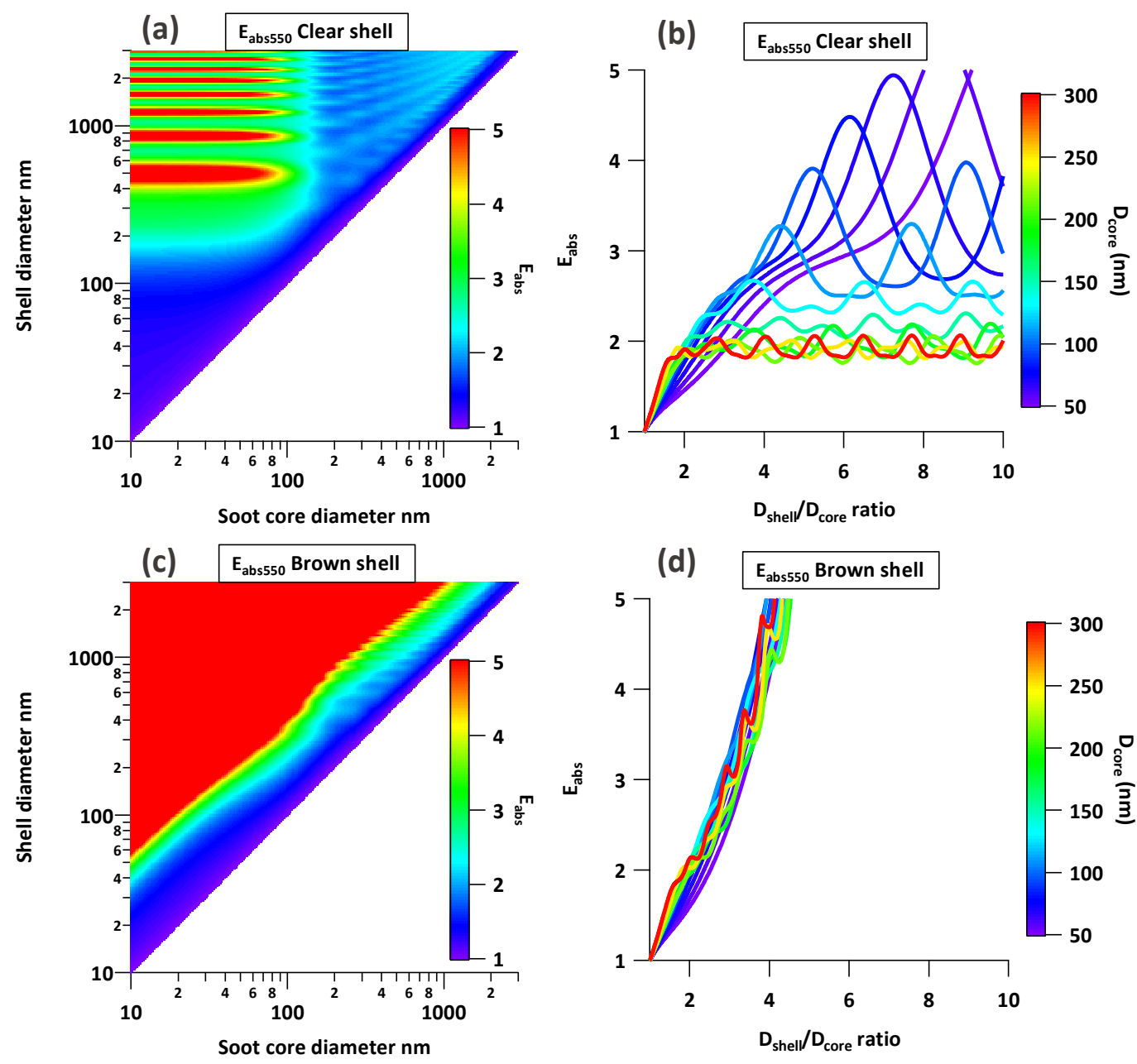

Figure 3. Mie simulated size dependency of soot particles $E_{\text {abs }}$ at wavelength $550 \mathrm{~nm}$. (a) Combination of different clear shell ( $y$ axis) and core diameters ( $x$ axis). The color coding represents the $E_{\text {abs }}$ of a particle with specific core and clear shell size; (b) cross-section views of (a). The color coding represents different $D_{\text {core }}$ in the range of 50-300 nm. (c, d) Similar to panels (a) and (b) but for the brown shell scenario.

is comparable to the lensing effect contribution, each contributing $\sim 50 \%$ to the total $E_{\text {abs }}$. When the BrC coating is sufficiently thick ( $>30 \mathrm{~nm}$ for $\lambda$ at $370 \mathrm{~nm},>90 \mathrm{~nm}$ for $\lambda$ at $550 \mathrm{~nm}$ and $>110 \mathrm{~nm}$ for $\lambda$ at $880 \mathrm{~nm}$ ), BrC absorption dominates the $E_{\text {abs }}$ contribution. As a result, if $\mathrm{BrC}$ coating is indeed present in ambient samples, a strong wavelengthdependent $E_{\text {abs }}$ can be observed, since a $\mathrm{BrC}$ coating of $30 \mathrm{~nm}$ is enough to induce a large amount of detectable $E_{\text {abs }}$ in the UV range. Another major difference between the clear and brown shell scenarios is that, for thickly coated particles (e.g., $D_{\text {coat }} / D_{\text {core }}>2$ ), the brown shell can yield a much higher $E_{\text {abs }}$ than the clear shell.

Both primary soot size distribution and coating thickness can affect the absorption enhancement of ambient BC particles. Ambient measurements from LII found soot particle number and mass modes peaking at 110 and $220 \mathrm{~nm}$, respectively, in the PRD (Huang et al., 2011). A study in Shanghai found similar results $(70 \mathrm{~nm}$ for number concentrations and $200 \mathrm{~nm}$ for mass concentrations; Gong et al., 2016). Considering that the $\mathrm{LII}$ technique is specific to $\mathrm{BC}$ mass determination which is independent of $\mathrm{BC}$ mixing state, the size distribution reported using LII is able to represent the size distribution of the BC core. A study using a micro-orifice uniform deposit impactor (MOUDI) found a EC mass size distribution in the PRD exhibiting three modes peaking at $\sim 300$, $\sim 900$ and $\sim 5000 \mathrm{~nm}$ (Yu et al., 2010), implying a substantial coating of $\mathrm{BC}$ particles, and a diameter amplification of 3. BC sizing from LII is based on volume-equivalent diameter (VED), while MOUDI is based on aerodynamic diameter. As a result, these two techniques do not necessarily yield similar sizes, even for the bare soot particles. The conversion between these two types of diameters involves the knowledge of particle density and morphology (drag force). A recent closure study on $\mathrm{BC}$ mixing state in the PRD region sug- 

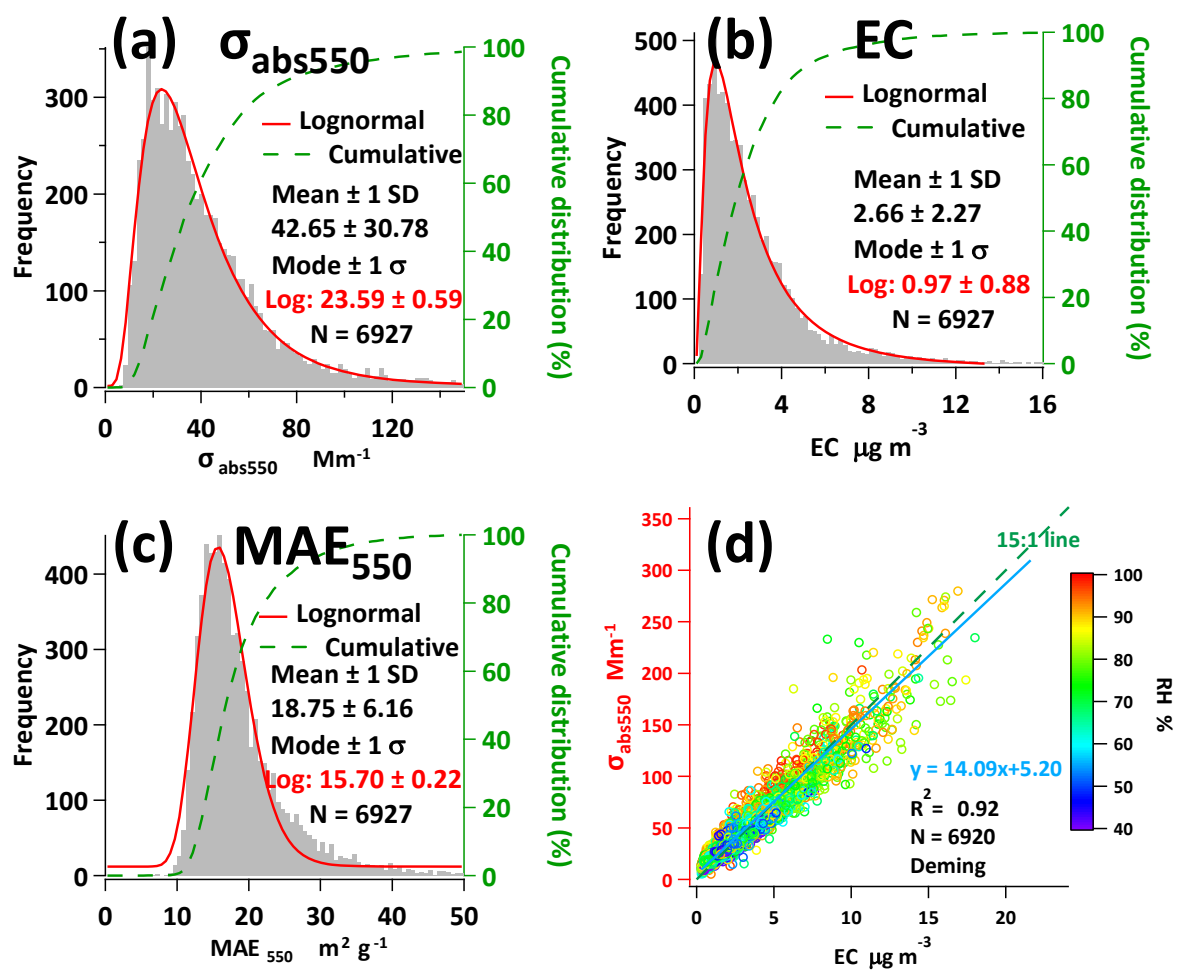

Figure 4. Measured annual statistics of $\sigma_{\mathrm{abs550}}, \mathrm{EC}$ and $\mathrm{MAE}_{550}$. (a) Annual frequency distribution of light absorption at $550 \mathrm{~nm}$. The red curve represents the fitting line for a lognormal distribution. (b) Annual frequency distribution of EC mass concentration. (c) Frequency distribution of Mass absorption efficiency (MAE) at $550 \mathrm{~nm}$. (d) Scatter plot of light absorption (550 nm) and EC mass. The slope represents $\mathrm{MAE}_{550}$. The blue regression line is made using Deming regression. The color coding represents RH.

gests $\sigma_{\mathrm{abs}}$ is dominated by coated soot particles in the range of 300-400 nm (Tan et al., 2016). Considering the dominant BC core distribution measured with SP2 $(110 \mathrm{~nm})$, the upper limit of $E_{\text {abs }}$ in the PRD is roughly estimated as $\sim 2$ for the clear shell scenario (Fig. 3b).

\section{Results and discussions}

\subsection{Annual measurement statistics}

The frequency distribution (lognormal) of $\sigma_{\mathrm{abs} 550}$ is shown in Fig. 4a, with an annual average ( \pm 1 SD) of $42.65 \pm$ $30.78 \mathrm{Mm}^{-1}$. A lognormal distribution is also found in the EC mass concentration (Fig. 4b), with an annual average of $2.66 \pm 2.27 \mu \mathrm{g} \mathrm{m}^{-3}$. Figure $4 \mathrm{c}$ demonstrates the 1-year frequency distribution of $\mathrm{MAE}_{550}$ at the $\mathrm{NC}$ site. The annual average $\mathrm{MAE}_{550}$ is $18.75 \pm 6.16 \mathrm{~m}^{2} \mathrm{~g}^{-1}$ and the peak $( \pm 1 \mathrm{SD})$ of the lognormal fit is $15.70 \pm 0.22 \mathrm{~m}^{2} \mathrm{~g}^{-1}$. A good correlation is observed between $\sigma_{\mathrm{abs}}$ and EC mass $\left(R^{2}=0.92\right)$ as shown in Fig. 4d, and the color coding indicates a MAE dependency on $\mathrm{RH}$, which agrees with a study in Xi' an (Y. Wu et al., 2016). Annual average $\mathrm{AAE}_{470-660}$ is $1.09 \pm 0.13$ (Fig. S8a), indicating that soot is the dominant absorbing substance in the PRD and the brown shell scenario shown in the Mie simulation is unlikely to be important. Annual mean $\mathrm{SSA}_{525}$ is $0.86 \pm 0.05$ (Fig. S8c), similar to previous studies in the PRD (Jung et al., 2009; Wu et al., 2009). For comparison purpose, MAE measured at original wavelength and MAE scaled to $550 \mathrm{~nm}$ following the $\lambda^{-1}$ assumption are both shown in Table S1. The MAE comparisons discussed below are MAE at $550 \mathrm{~nm}$. MAE 550 in previous studies at various locations was found to cover a wide range, from 5.9 to $61.6 \mathrm{~m}^{2} \mathrm{~g}^{-1}$. Annual average observed $\mathrm{MAE}_{550}$ at $\mathrm{NC}$ $\left(18.75 \mathrm{~m}^{2} \mathrm{~g}^{-1}\right)$ is higher than many studies shown in Fig. 5, e.g., Shenzhen (Lan et al., 2013), Beijing (Yang et al., 2009), Mexico City (Doran et al., 2007) and Fresno (Chow et al., 2009).

As shown in Fig. 1, the annual average $\mathrm{MAE}_{\mathrm{p}, 550}$ estimated from MRS is $13 \mathrm{~m}^{2} \mathrm{~g}^{-1}$. $\mathrm{MAE}_{\mathrm{p}}$ from MRS represents the $\mathrm{MAE}_{\mathrm{p}}$ at the emission source, which is different from the $\mathrm{MAE}_{\mathrm{p}}$ found in the TD approach for two reasons. First, the morphology of thermally denuded $\mathrm{BC}$ particles (compact aggregates) is different from that of freshly emitted BC particles (chain-like aggregates). Second, most of the coatings are removed for TD denuded soot particles, but freshly emitted soot particles usually come with a thin coating of OC formed from condensation of $\mathrm{OC}$ vapors as the temperature drops from the engine to the ambient air. As a result, the MRSderived $\mathrm{MAE}_{\mathrm{p}}$ is expected to be higher than the $\mathrm{MAE}_{\mathrm{p}}$ in the 


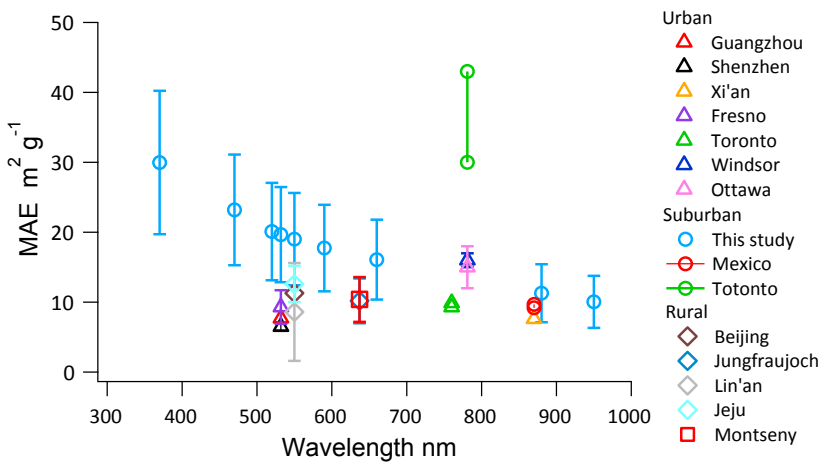

Figure 5. Comparison of spectral MAE measurements from this study with previous studies. Triangle, circle and rhombus represent urban, suburban and rural, respectively. Details and reference can be found in Table S1. The whiskers represent 1 SD.

TD approach. The estimated $\mathrm{MAE}_{\mathrm{p}, 550}$ is higher than a previous study in Guangzhou (7.44 $\mathrm{m}^{2} \mathrm{~g}^{-1}$; Andreae et al., 2008), but comparable to Xi' an $\left(11.34 \mathrm{~m}^{2} \mathrm{~g}^{-1}\right.$; Wang et al., 2014) and Toronto ( $\sim 9.53-12.57 \mathrm{~m}^{2} \mathrm{~g}^{-1}$; Knox et al., 2009). The annual average $E_{\text {abs550 }}$ from MRS following Eq. (3) is estimated to be $1.50 \pm 0.48$ (mean $\pm 1 \mathrm{SD}$ ).

As mentioned in Sect. 1, the definition of $\mathrm{MAE}_{\mathrm{p}}$ from the TD approach is different from the $\mathrm{MAE}_{\mathrm{p}}$ of the emission source. The TD MAE $E_{p}$ is expected to be slightly lower than the $\mathrm{MAE}_{\mathrm{p}}$ of the emission source. Therefore, the corresponding $E_{\text {abs }}$ values are slightly different and care should be taken when comparing MRS-derived $E_{\text {abs }}$ with $E_{\text {abs }}$ from the TD approach and Mie simulations. The $E_{\text {abs }}$ could vary by location, depending on the coating thickness and size distribution of the primary aerosols. After undergoing atmospheric aging, the $E_{\text {abs }}$ can increase during transport from emission source to rural areas. The magnitude of the $E_{\mathrm{abs}}$ found at the $\mathrm{NC}$ site is comparable to other locations such as Boulder (Lack et al., 2012a; 1.38), London (Liu et al., 2015; 1.4), Shenzhen (Lan et al., 2013; 1.3), Yuncheng (X. Cui et al., 2016; 2.25), Jinan (Chen et al., 2017; 2.07) and Nanjing (F. Cui et al., 2016; 1.6) and is higher than studies in California (Cappa et al., 2012; 1.06), as listed in Table 3. Spectrum $E_{\text {abs }}$ values are calculated from 370 to $950 \mathrm{~nm}$ as shown in Fig. S9. $E_{\text {abs }}$ in the PRD exhibits a weak wavelength dependence, with slightly higher $E_{\mathrm{abs}}$ at the shorter wavelength (e.g., $E_{\text {abs } 370}=1.55 \pm 0.48$ ) and relatively lower in the IR range (e.g., $E_{\text {abs } 950}=1.49 \pm 0.49$ ).

\subsection{Monthly characteristics of MAE, AAE and SSA}

Monthly variations of $\mathrm{MAE}_{550}$ at the NC site are shown in Fig. 6a and Table S2, revealing distinct patterns of higher $\mathrm{MAE}_{550}$ in summer and lower in winter. On the other hand, $\mathrm{AAE}_{470-660}$ is lower in summer and higher in winter (Fig. 6b and Table S3). Monthly SSA 525 varied from 0.83 to 0.90 without a clear seasonal pattern, as shown in Fig. S10 and Ta-
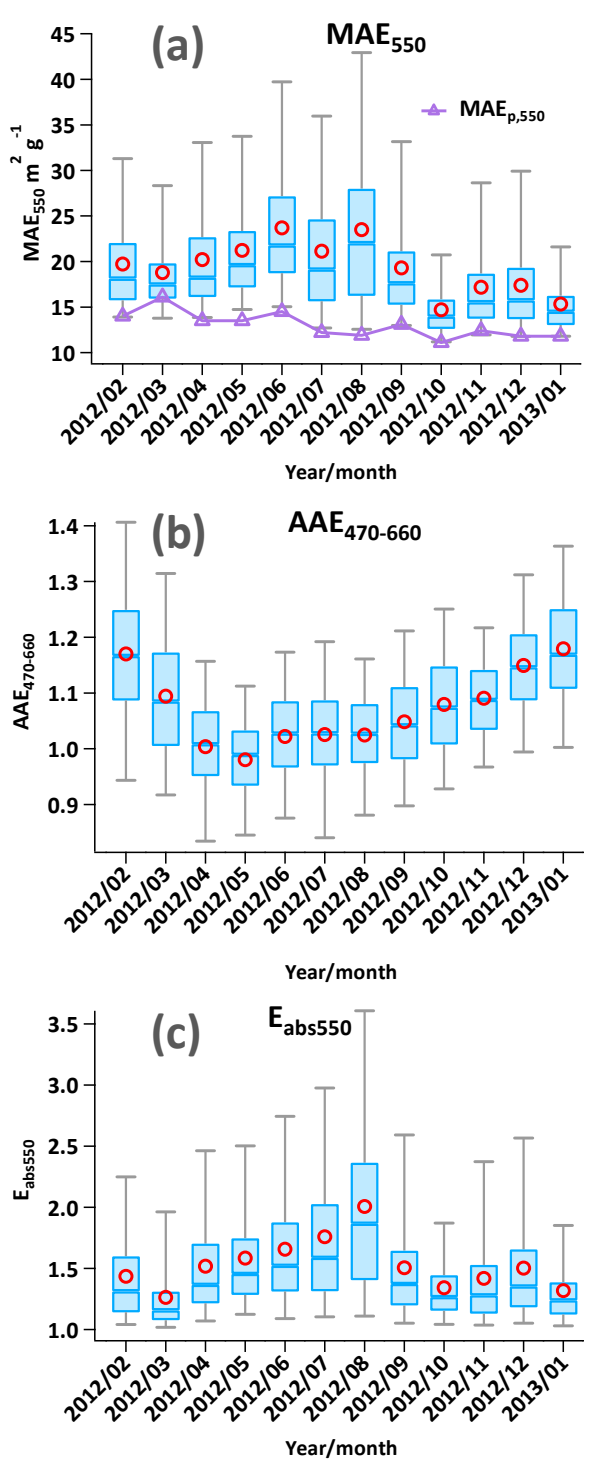

Figure 6. Measured monthly variations of (a) $\mathrm{MAE}_{550}$; the purple line represents $\mathrm{MAE}_{\mathrm{p}, 550}$ estimated from MRS (b) $\mathrm{AAE}_{470-660}$ and (c) $E_{\text {abs550. Red circles represent the monthly average. The }}$ line inside the box indicates the monthly median. Upper and lower boundaries of the box represent the 75th and the 25th percentiles; the whiskers above and below each box represent the 95th and 5th percentiles.

ble $\mathrm{S} 4 . \mathrm{MAE}_{\mathrm{p}, 550}$ estimation for individual months is shown in Fig. 6a (the purple line) and monthly $E_{\text {abs550 }}$ is calculated accordingly following Eq. (3) (Fig. 6c). $E_{\text {abs550 }}$ shows clear seasonal variations, with higher values from April to August $(\sim 1.52-1.97$ as shown in Table S5) and relatively lower values from September to March $(\sim 1.24-1.49)$. The highest enhancement is found in August (1.97). Factors affecting variation of $E_{\text {abs550 }}$ are discussed in the following sections, including air mass origin and biomass burning. 
Table 3. Comparison of $E_{\mathrm{abs}}$ among various studies.

\begin{tabular}{lllrlrll}
\hline Location & Type & Sampling duration & $\lambda(\mathrm{nm})$ & Instrument & $E_{\text {abs }}$ & Method & Reference \\
\hline Guangzhou, China & Suburban & Feb 2012-Jan 2013 & 550 & AE+OCEC & $1.50 \pm 0.48$ & MAE & This study \\
Xi'an, China & Urban & Dec 2012-Jan 2013 & 870 & PAS & 1.8 & MAE & (Wang et al., 2014) \\
Shenzhen, China & Urban & Aug-Sep 2011 & 532 & PAS & 1.3 & MAE & (Lan et al., 2013) \\
Jinan, China & Urban & Feb 2014 & 678 & OCEC & $2.07 \pm 0.72$ & AFD & (Chen et al., 2017) \\
Nanjing, China & Suburban & Nov 2012 & 532 & PAS & 1.6 & MAE & (F. Cui et al., 2016) \\
Boulder, USA & Forest fire & Sep 2010 & 532 & PAS & 1.38 & TD 200 ${ }^{\circ} \mathrm{C}$ & (Lack et al., 2012a) \\
London, UK & Rural & Feb 2012 & 781 & PAS & 1.4 & TD 250 C & (Liu et al., 2015) \\
California, USA & Rural & Jun 2010 & 532 & PAS & 1.06 & TD 250 C & (Cappa et al., 2012) \\
Noto Peninsula, Japan & Rural & Apr-May 2013 & 781 & PAS & 1.22 & TD 300 ${ }^{\circ} \mathrm{C}$ & (Ueda et al., 2016) \\
Yuncheng, China & Rural & Jun-Jul 2014 & 678 & OCEC & $2.25 \pm 0.55$ & AFD & (X. Cui et al., 2016) \\
San Jose, Costa Rica & Rural & winter 2006 & 1064 & SP2 & 1.3 & Mie + SP2 & (Schwarz et al., 2008) \\
\hline
\end{tabular}

AE: Aethalometer; OCEC: OCEC analyzer; PAS: photoacoustic spectrometer; SP2: single-particle soot photometer; TD: thermodenuder; AFD: aerosol filter filtration-dissolution; Mie: Mie calculation

\subsection{The effect of air mass origin}

Understanding the seasonal variations of optical properties in the PRD is of great interest. Hourly backward trajectories for the past $72 \mathrm{~h}$ were calculated using NOAA's HYSPLIT (Hybrid Single Particle Lagrangian Integrated Trajectory, version 4) model (Draxier and Hess, 1998) from February 2012 to January 2013 as shown in Fig. S11. Cluster analysis was conducted using MeteoInfo (Wang, 2014). By examining the total spatial variance (TSV), the number of clusters was determined to be four as shown in Fig. S12. Cluster 1 (C1) represents continental air masses from the north, accounting for $44.4 \%$ of total trajectories. C2 $(22.8 \%)$ represents marine air masses coming from the South China Sea. C3 represents air masses from the east (Taiwan). C4 (15.8\%) represents transitional air masses coming from the east coastline of China. As shown in Fig. 7, $E_{\text {abs550 }}$ from C2 (1.78) is higher than other clusters (1.30-1.42). Further Wilcoxon-Mann-Whitney tests show that $E_{\text {abs } 550}$ from $\mathrm{C} 2$ is significantly higher than $E_{\text {abs550 }}$ from $\mathrm{C} 1, \mathrm{C} 3$ and $\mathrm{C} 4$ (Fig. S13), implying that particles from the South China Sea cluster is likely more aged than other clusters. Air mass origin in the PRD is dominated by $\mathrm{C} 2$ from April to August (Fig. S14a) as a result of the South China Sea monsoon in the rainy season. In contrast, the dry season is ruled by continental air masses from the north $(\mathrm{C} 1)$ due to the influence of the northeast monsoon. $E_{\text {abs550 from C2 }}$ varied from 1.67 to 2.19 , but was always higher than $E_{\text {abs550 }}$ from $\mathrm{C} 1$ and $\mathrm{C} 3$ during the rainy season (Fig. S14b). As a result, the domination of aged air mass from the vast ocean is one of the reasons for the much higher $E_{\text {abs550 }}$ found in the rainy season.

\subsection{The effect of biomass burning}

Biomass burning (BB) and vehicular emission are the two major sources of soot particles. BC from biomass burning emission, depending on the fuel type and burning condition, may have a higher OC / EC ratio and a thicker coating, re-

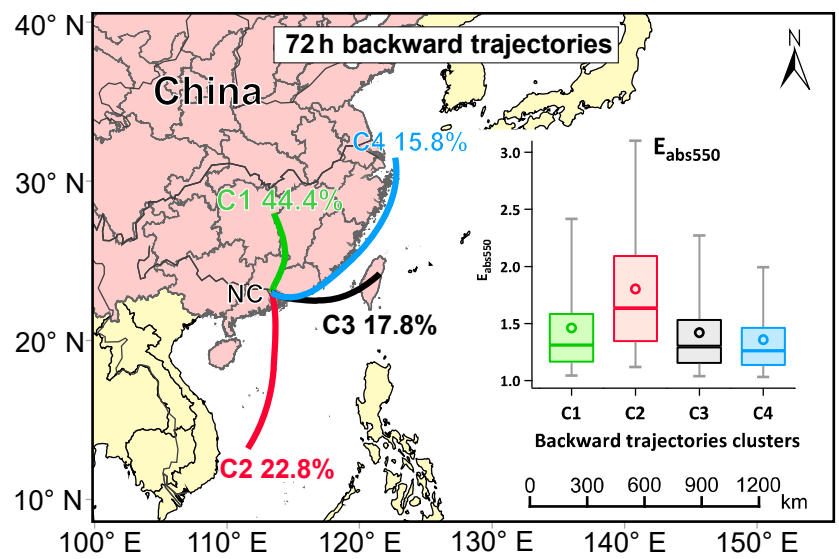

Figure 7. Average backward trajectories arriving at $100 \mathrm{~m}$ at $\mathrm{NC}$ site for four clusters (February 2012-January 2013). $E_{\text {abs550 from }}$ different clusters are shown in the box plot.

sulting in a higher MAE than vehicular emission (Shen et al., 2013; Cheng et al., 2016). In this study, the influence of $\mathrm{BB}$ on optical properties is investigated using the $\mathrm{K}^{+} / \mathrm{EC}$ ratio as a $\mathrm{BB}$ indicator. As shown in Fig. 8, $\mathrm{MAE}_{550}$ is positively correlated with the $\mathrm{K}^{+} / \mathrm{EC}$ ratio, which exhibits a clear seasonal pattern that is higher in the rainy season and lower in the dry season (Fig. S15a). Southeast Asia has the highest fire emission density globally due to the high biofuel consumption along with frequent fire activity in this region (Aouizerats et al., 2015), making Southeast Asia a large contributor to BC emissions (Jason Blake, 2014). During the rainy season when oceanic wind prevails, $\mathrm{BC}$ from $\mathrm{BB}$ emissions in Southeast Asia can reach PRD through longrange transport, resulting in an elevated $\mathrm{K}^{+} / \mathrm{EC}$ ratio and $\mathrm{MAE}_{550}$. The Deming regression intercept (11.89) in Fig. 8 represents the MAE without the $\mathrm{BB}$ effect. This non-BB $\operatorname{MAE}_{550}\left(11.89 \mathrm{~m}^{2} \mathrm{~g}^{-1}\right)$ is only slightly lower than $\mathrm{MAE}_{\mathrm{p}, 550}$ $\left(13 \mathrm{~m}^{2} \mathrm{~g}^{-1}\right)$ obtained in Sect. 4.1, implying that a large frac- 


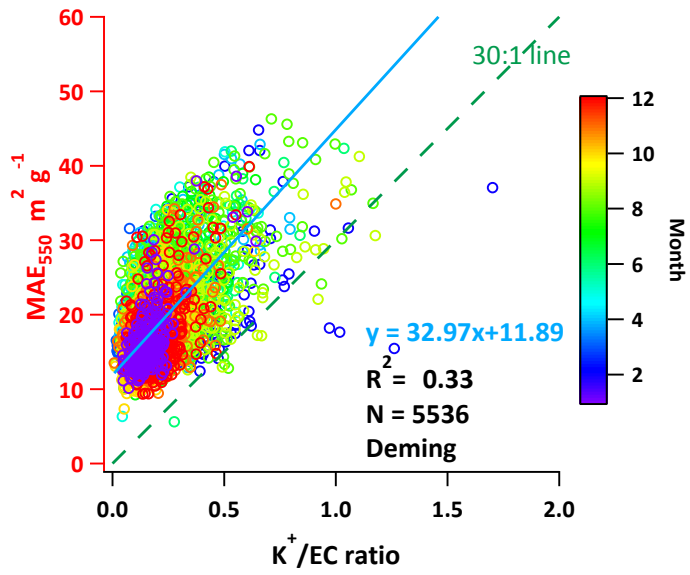

Figure 8. $\mathrm{MAE}_{550}$ dependency on biomass burning indicator $\mathrm{K}^{+} / \mathrm{EC}$ ratio. The color coding represents months. The intercept represents MAE without biomass burning effect. The 30:1 line serves as a reference line with an integer slope that is close to the regressed slope through the origin.

tion of $\mathrm{MAE}_{\mathrm{p}, 550}$ could not be explained by the BB source. Additional evidence was obtained through examining regression relationships of $\mathrm{MAE}_{\mathrm{p}, 550}$ with $\mathrm{K}^{+} / \mathrm{EC}$ month by month (Fig. S15b). Correlation of monthly $\mathrm{MAE}_{\mathrm{p}, 550}$ vs. $\mathrm{K}^{+} / \mathrm{EC}$ ratio yields an $R^{2}$ of 0.23 (Fig. $\mathrm{S} 15 \mathrm{c}$ ). In contrast, a much higher correlation $\left(R^{2}=0.58\right)$ was observed (Fig. S15d) between $\mathrm{MAE}_{\mathrm{p}, 550}$ and non-BB MAE 550 (i.e., $\mathrm{K}^{+} / \mathrm{EC}$ intercepts from Fig. S15b). These results imply that $\mathrm{BB}$ is one of the contributors to the $\mathrm{MAE}_{\mathrm{p}, 550}$ variations, but unlikely the dominating one.

Many studies have found that BB-influenced samples exhibit elevated AAE due to the presence of wavelengthdependent light absorbing substances like $\mathrm{BrC}$ and humiclike substances (HULIS; Kirchstetter et al., 2004; Hoffer et al., 2006; Sandradewi et al., 2008; Herich et al., 2011; Pokhrel et al., 2017). Investigating whether elevated AAE observed in the PRD during the dry season is associated with BB influence is of great interest. As shown in Fig. S16, $\mathrm{AAE}_{370-470}$ and $\mathrm{AAE}_{470-660}$ did not correlate with the BB indicator, $\mathrm{K}^{+} / \mathrm{EC}$ ratio. These results suggest that the elevated AAE observed in the PRD wintertime is unlikely to be dominated by the $\mathrm{BB}$ effect. Beside the independency between $\mathrm{AAE}_{470-660}$ and $\mathrm{K}^{+} / \mathrm{EC}$ ratio, the measured $\mathrm{AAE}_{470-660}$ range also implies that $\mathrm{BB}$ is not the major driving force of $\mathrm{AAE}_{470-660}$ variations. The limited light absorption contribution from $\mathrm{BrC}$ in PRD region is observed in a recent study (Yuan et al., 2016), which suggest an upper limit of $\mathrm{BrC}$ contribution of $10 \%$ at $405 \mathrm{~nm}$ in the winter time using the AAE approach. As discussed in our Mie simulation (Sect. 3.2) and a previous study (Lack and Cappa, 2010), coating of non-absorbing materials onto soot particles can increase AAE up to 2 . Since the monthly average AAE $_{470-660}$ in wintertime did not exceed 1.2 (Table S3), the variations of $\mathrm{AAE}_{470-660}$ in the PRD are more likely associated with coatings rather than the contribution of $\mathrm{BrC}$. The results also imply that attempts at attributing $\mathrm{BrC}$ absorption for the PRD data set presented in this study could be risky, considering that elevation of AAE is actually dominated by coating (Lack and Langridge, 2013).

\subsection{Implications for mixing state}

Quantitative direct measurements of BC mixing state and coating thickness are still challenging. SP2 can estimate the coating thickness using a lag-time approach or a Mie calculation approach can be employed, but both methods have a limited range in coating thickness and uncertainties arise from the assumptions made during the retrieval. For example, recent studies found that the mass-equivalent diameter of soot core measured by SP2 could be underestimated due to density assumptions (Y. Zhang et al., 2016). Although size distribution measurement is not available in this study, clues regarding mixing state still can be derived from bulk measurements of optical properties. As discussed in Sect. 4.3, elevated $E_{\text {abs550 }}$ observed in the rainy season is associated with aged air masses from a marine origin. To probe the possible mixing state difference between dry and rainy season, $E_{\text {abs550, }} \mathrm{SSA}_{525}$ and $\mathrm{AAE}_{470-660}$ values are used to narrow down the possible core-shell size range as shown in Fig. S17. Monthly averages with 1 SD of $\mathrm{AAE}_{470-660}$, $\mathrm{SSA}_{525}$ and $E_{\text {abs550 }}$ are used as constraints to extract the intersecting core-shell size range from Figs. 2a, S4 and 3a. January and August data are used to represent two different scenarios: elevated $\mathrm{AAE}_{470-660}(1.19 \pm 0.11)$ with lower $E_{\text {abs550 }}$ $(1.31 \pm 0.32)$ in dry season and low $\mathrm{AAE}_{470-660}(1.04 \pm 0.09)$ with elevated $E_{\text {abs550 }}(1.97 \pm 0.71)$ in rainy season. The results show that January and August have a very different core-shell size range: in January, the core and shell ranges are $\sim 100-160 \mathrm{~nm}$ and $\sim 120-250 \mathrm{~nm}$, respectively; in August, the core and shell ranges are $\sim 120-165 \mathrm{~nm}$ and $\sim 170$ $430 \mathrm{~nm}$, respectively. This confirms again that the soot particles in the rainy season are likely to have a thicker coating than in the dry season.

\section{Caveats of the MRS method in its application to ambient data}

\subsection{Impact of measurement biases}

It should be noted that the $E_{\text {abs }}$ estimation approach is insensitive to the systematic MAE bias (e.g., systematic overestimation of $\sigma_{\mathrm{abs}}$ and variability of EC mass from different TOA protocols) discussed in Sect. 2.1, because systematic bias in EC mass or $\sigma_{\text {abs }}$ is canceled out in the $E_{\text {abs }}$ calculation (Eq. 3), since $E_{\mathrm{abs}}$ is the ratio of $\sigma_{\mathrm{abs}, \mathrm{t}}$ to $\sigma_{\mathrm{abs}, \mathrm{p}}$. To investigate the performance of the MRS approach in response to systematic bias in EC and $\sigma_{\text {abs }}$, two simple tests are conducted as shown in Figs. S18 and S19 by adding systematic 
biases to the original data. The 1-year measurement data of $\sigma_{\text {abs550 }}$ and EC are used as original data. Test A represents a situation when $\sigma_{\mathrm{abs}}$ is overestimated and EC is underestimated. The biased data are marked as $\sigma^{\prime}{ }_{\text {abs550 }}$ and $\mathrm{EC}^{\prime}$, respectively, as shown below:

$\sigma^{\prime}{ }_{\text {abs550 }}=\sigma_{\text {abs550 }} \times 2$,

$\mathrm{EC}^{\prime}=\mathrm{EC} \times 0.7$.

As a result, the average $\mathrm{MAE}_{550}$ changed from 18.75 to $53.58 \mathrm{~m}^{2} \mathrm{~g}^{-1}$ and $\mathrm{MAE}_{\mathrm{p}}$ changed from 13 to $37 \mathrm{~m}^{2} \mathrm{~g}^{-1}$ (Fig. S18). However, $E_{\text {abs }}$ values from the ratio of averages remain the same (1.44).

In Test B, EC from different TOA protocols are compared to investigate the effect of different EC determination approaches while $\sigma_{\text {abs550 }}$ remains unchanged. EC from IMPROVE TOR protocol is calculated from NIOSH TOT EC following an empirical formula for suburban sites derived from a 3-year OCEC data set in PRD (C. Wu et al., 2016):

$\mathrm{EC}_{\text {IMP_TOR }}=2.63 \times \mathrm{EC}_{\mathrm{NSH} \_\mathrm{TOT}}+0.05$.

As shown in Fig. S19, MAE 550 changed from 18.75 to $7.02 \mathrm{~m}^{2} \mathrm{~g}^{-1}$ and $\mathrm{MAE}_{\mathrm{p}}$ changed from 13 to $5 \mathrm{~m}^{2} \mathrm{~g}^{-1}$, but $E_{\text {abs }}$ remain almost the same (1.40). The result of Test B implies that although EC is operationally defined, the discrepancy of EC between TOA protocols did not weaken the role of EC in serving as a tracer for primary emissions in MRS application. These examples demonstrate that systematic biases in $\sigma_{\text {abs550 }}$ and EC have no effects on $E_{\text {abs }}$ estimation from the MRS approach.

A study by Cheng et al. (2016) found two distinct types of biomass smoke behave differently on the biases of filterbased $\sigma_{\text {abs }}$ measurement. The bias in the first type can be explained by a nearly constant correction factor, which is similar to the situation discussed in Test A. The bias in the second type shows an apparent OC / EC dependence. Test C is carried out to investigate this situation, i.e., examining the impact of sample-dependent bias as a function of $E_{\text {abs }}$. Unlike the proportional bias in Test $\mathrm{A}$ and $\mathrm{B}$ that is the same for all data points, the bias in Test $\mathrm{C}$ depends on the $E_{\text {abs550 }}$ of individual samples, which are parametrized in Eqs. (11) and (12).

$\sigma_{\text {abs550 }}^{\prime}=\sigma_{\mathrm{abs550}}+\sigma_{\mathrm{abs} 550} \times\left(k \times E_{\mathrm{abs} 550}-k\right)$

$\mathrm{EC}^{\prime}=\mathrm{EC}-\mathrm{EC} \times\left(k \times E_{\mathrm{abs} 550}-k\right)$

As shown in Eqs. (11) and (12), the positive bias of $\sigma_{\text {abs550 }}$ and negative bias of EC are proportional to $E_{\text {abs550. The mag- }}$

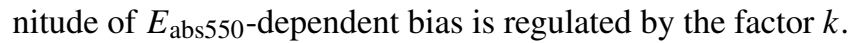
Since $\sigma^{\prime}{ }_{\text {abs550 }}$ and $\mathrm{EC}^{\prime}$ are biased in different directions, resulting in further amplification of MAE biases, which could be considered as the extreme case. As shown in Fig. S20, for $k=10 \%$ (corresponding to a bias of $10 \%$ when $E_{\mathrm{abs}}=2$ ), the bias of MRS-derived $E_{\mathrm{abs}}$ is very small $(1 \%)$. For $k=$
$20 \%$, the MRS-derived $E_{\text {abs }}$ changes from 1.44 to 1.66 , leading to a bias of $15 \%$. These results imply that if the measurement bias follows the same form as demonstrated in Test $\mathrm{C}$, the bias is not negligible but still acceptable. If the impact only affects $\sigma_{\mathrm{abs}}$ or EC rather than impacting both, the bias is expected to be smaller than the estimation shown in Test $\mathrm{C}$.

It should be noted that the parameterization scheme shown in Eqs. (11) and (12) is only for demonstration purposes from a conceptual perspective and it does not necessarily represent real-world measurements. There is a lack of quantitative understanding of this impact. For example, Lee et al. (2007) used artificially fabricated EC samples with OC coatings to evaluate the impact of coating on OC/EC analysis. Biases were observed; nevertheless, the results were linearly correlated with the true OC and EC values with a high $R^{2}(>0.9)$, implying that the biases in that specific study were dominated by systematic biases rather than the coating-dependent bias. Further studies are needed to better characterize and parameterize this impact if filter-based techniques are used for $\sigma_{\mathrm{abs}}$ and EC determination in the MRS approach.

\subsection{Impact of semi-volatile organic carbon}

Light absorption contribution due to semi-volatile organic carbon (SVOC) from wood combustion was reported to be negligible in the visible range and around 10-20\% at $360 \mathrm{~nm}$ (Chen and Bond, 2010). On the other hand, OCEC analysis can be affected by SVOC (Subramanian et al., 2004), either by positive artifacts through adsorption of SVOC onto quartz filters or by negative artifacts through evaporation of SVOC due to the gas-particle re-equilibrium downstream of the VOC denuder. Positive artifacts can be minimized by the installation of a VOC denuder which is widely adopted in RTOCEC measurements (Bae et al., 2004; Bauer et al., 2009). A typical negative artifact of $10 \%$ is expected and can be corrected by backup filters (Subramanian et al., 2004). There was evidence to show that SVOC could affect OC / EC split in thermal-optical analysis (Cheng et al., 2009). However, the bias in EC caused by the OC / EC split drift due to SVOC is systematic, making it fall into the scenario discussed in Test B. As a result, the impact from SVOC on $E_{\text {abs }}$ estimation from MRS is expected to be small.

\subsection{Impact of mineral dust}

The presence of mineral dust (MD) could affect both $\sigma_{\text {abs }}$ and EC determination. If MD is externally mixed with soot particles, the light absorption from MD could be miscounted as $\sigma_{\text {abs }}$ enhancement, leading to the overestimation of $E_{\text {abs }}$. If the light absorption signal from MD is sufficiently strong (e.g., AAE > 2), $\sigma_{\text {abs }}$ of MD and BC can be separated with the AAE approach suggested by Fialho et al. (2005). Additionally, the presence of substantial MD in samples has several impacts on the EC determination in thermal analysis. First, if the samples are not pre-treated with acid, the carbon- 
ated carbon could be misidentified as EC, resulting in overestimation of EC (Chow et al., 1993). The acid treatment is only available for offline OC / EC analysis and not yet practical for the RT-OCEC analyzer. Second, metal oxides in MD can lead to premature EC oxidation in the helium stage of OC / EC analysis, leading to underestimation of EC (Wang et al., 2010; Bladt et al., 2012). The lack of a parameterization scheme for correcting the EC loss due to MD makes it improper to use the biased EC as a primary tracer. For these reasons, $E_{\text {abs }}$ estimation with MRS is not recommended for samples strongly influenced by MD.

\subsection{Impact of $\mathrm{BrC}$}

The data in this study is dominated by $\mathrm{BC}$ absorption that did not show much influence from $\mathrm{BrC}$. However, extra care should be taken if the samples exhibit substantial $\mathrm{BrC}$ signature (e.g., AAE > 2). Such situations are equivalent to the two-source scenarios discussed in our previous paper on the MRS method (Wu and $\mathrm{Yu}, 2016)$ and the major findings are described below. Two types of two-source scenarios are considered: two correlated primary sources (scenario A) and two independent primary sources (scenario B). In scenario A, in which both $\mathrm{BC}$ and primary $\mathrm{BrC}$ are dominated by $\mathrm{BB}$, using $\mathrm{BC}$ as a solo tracer to calculate the primary ratio $\left(\mathrm{MAE}_{\mathrm{p}}\right)$ still works. In scenario $\mathrm{B}$, in which $\mathrm{BC}$ and primary $\mathrm{BrC}$ are independent, using $\mathrm{BC}$ alone to determine a single primary $\mathrm{MAE}_{\mathrm{p}}$ could lead to a considerable bias in $E_{\mathrm{abs}}$ estimation. Alternatively, if a reliable primary $\mathrm{BrC}$ tracer is available, the corresponding $\mathrm{MAE}_{\mathrm{p}, \mathrm{BrC}}$ can be determined with MRS. With the knowledge of $\mathrm{MAE}_{\mathrm{p}, \mathrm{BrC}}$ and $\mathrm{MAE}_{\mathrm{p}, \mathrm{BC}}$, light absorption by $\mathrm{BC}$ and $\mathrm{BrC}$ can be calculated separately and the $E_{\mathrm{abs}}$ can be determined using Eq. (13):

$$
\begin{aligned}
& E_{\mathrm{abs}}=\frac{\sigma_{\mathrm{abs}, \mathrm{t}}}{\sigma_{\mathrm{abs}, \mathrm{p}, \mathrm{BC}}+\sigma_{\mathrm{abs}, \mathrm{p}, \mathrm{BrC}}} \\
& =\frac{\sigma_{\mathrm{abs}, \mathrm{t}}}{\mathrm{MAE}_{\mathrm{p}, \mathrm{BC}} \times \mathrm{EC}+\mathrm{MAE}_{\mathrm{p}, \mathrm{BrC}} \times \mathrm{BrC}} .
\end{aligned}
$$

However, the implementation of Eq. (13) is challenging due to the complexity in the chemical composition of $\mathrm{BrC}$. For example, a recent study found that the 20 most absorbing BrC chromophores account for $\sim 50 \%$ of BrC light absorption and there is not a single compound contributing more than $10 \%$ (Lin et al., 2016), making it difficult to choose a single compound as the $\mathrm{BrC}$ tracer. In addition, timeresolved measurement of $\mathrm{BrC}$ chromophores has yet to be developed. As a result, for scenario B (sample AAE $>2$ and primary $\mathrm{BrC}$ variations independent of $\mathrm{BC}$ ), estimation of $E_{\text {abs }}$ with MRS is not practical at this stage due to the lack of required input data. Using $\mathrm{BC}$ alone to determine a single primary $\mathrm{MAE}_{\mathrm{p}}$ could lead to a considerable bias and should be avoided.

\section{Conclusions}

In this study, a novel statistical approach is proposed and its application on ambient data is demonstrated using 1-year hourly OC and EC data coupled with Aethalometer measurements. Unlike conventional $E_{\text {abs }}$ determination approaches that require expensive instrumentation (e.g., TD-PAS, VTDMA, SP2), this new approach employs widely deployed instruments (field carbon analyzer and Aethalometer). The key of this new approach involves calculating $\mathrm{MAE}_{\mathrm{p}}$ using the minimum $R$ squared (MRS) method (Wu and $\mathrm{Yu}$, 2016). The MRS method opens up a new approach to investigate the long-term trend of $E_{\text {abs }}$ that has rarely been studied using the TD approach. It is found that $E_{\text {abs }}$ estimation from MRS is insensitive to systematic biases in EC and $\sigma_{\mathrm{abs}}$ measurements. The annual average $\mathrm{MAE}_{\mathrm{p}, 550}$ estimated with MRS is $13 \mathrm{~m}^{2} \mathrm{~g}^{-1}$ and annual average MAE 550 is $18.75 \pm 6.16 \mathrm{~m}^{2} \mathrm{~g}^{-1}$, suggesting an annual average enhancement factor $\left(E_{\text {abs550 }}\right)$ of $1.50 \pm 0.48$ in the PRD region. This value is within the upper limit of $E_{\mathrm{abs}}(\sim 2)$ in core-shell Mie simulations considering the typical soot size distribution and coating thickness in the PRD.

Both $\mathrm{MAE}_{\mathrm{p}, 550}$ and $E_{\mathrm{abs}}$ show distinct seasonal variations, implying the complexity of soot particle mixing state variations in this region. The elevated summertime $E_{\text {abs550 }}$ in the PRD is found to be associated with the domination of aged air masses from the South China Sea, along with the long-range transport of biomass-burning-influenced air masses from Southeast Asia. Core-shell size ranges narrowed down by the $E_{\text {abs550, }}, \mathrm{SSA}_{525}$ and $\mathrm{AAE}_{470-660}$ constraints suggest that soot particles in the rainy season are likely to have thicker coatings than in the dry season.

Data availability. OC, EC, inorganic ions and $\sigma_{\mathrm{abs}}$ data used in this study are available from the corresponding authors upon request. The computer programs used for data analysis and visualization in this study are available in $\mathrm{Wu}(2017 \mathrm{a}-\mathrm{e})$.

\section{The Supplement related to this article is available online at https://doi.org/10.5194/acp-18-289-2018-supplement.}

Competing interests. The authors declare that they have no conflict of interest.

Acknowledgements. This work is supported by the National Natural Science Foundation of China (41605002, 41475004). We gratefully acknowledge the Fok Ying Tung Foundation for funding to the Atmospheric Research Center at HKUST Fok Ying Tung Graduate School. The authors thank Jingxiang Huang of Fok Ying Tung Graduate School for assistance in OCEC analyzer maintenance. The authors are also grateful to Stephen M Griffith 
and Yongjie Li for the helpful comments. The authors gratefully acknowledge the NOAA Air Resources Laboratory (ARL) for the provision of the HYSPLIT transport and dispersion model used in this publication.

Edited by: Manabu Shiraiwa

Reviewed by: two anonymous referees

\section{References}

Adler, G., Riziq, A. A., Erlick, C., and Rudich, Y.: Effect of intrinsic organic carbon on the optical properties of fresh diesel soot, P. Natl. Acad. Sci. USA, 107, 6699-6704, https://doi.org/10.1073/pnas.0903311106, 2010.

Ajtai, T., Filep, Á., Utry, N., Schnaiter, M., Linke, C., Bozóki, Z., Szabó, G., and Leisner, T.: Inter-comparison of optical absorption coefficients of atmospheric aerosols determined by a multiwavelength photoacoustic spectrometer and an Aethalometer under sub-urban wintry conditions, J. Aerosol Sci., 42, 859-866, https://doi.org/10.1016/j.jaerosci.2011.07.008, 2011.

Alexander, D. T. L., Crozier, P. A., and Anderson, J. R.: Brown carbon spheres in East Asian outflow and their optical properties, Science, 321, 833-836, 2008.

Andreae, M. O., Schmid, O., Yang, H., Chand, D., Yu, J. Z., Zeng, L. M., and Zhang, Y. H.: Optical properties and chemical composition of the atmospheric aerosol in urban Guangzhou, China, Atmos. Environ., 42, 6335-6350, https://doi.org/10.1016/j.atmosenv.2008.01.030, 2008.

Aouizerats, B., van der Werf, G. R., Balasubramanian, R., and Betha, R.: Importance of transboundary transport of biomass burning emissions to regional air quality in Southeast Asia during a high fire event, Atmos. Chem. Phys., 15, 363-373, https://doi.org/10.5194/acp-15-363-2015, 2015.

Arnott, W. P., Moosmuller, H., Sheridan, P. J., Ogren, J. A., Raspet, R., Slaton, W. V., Hand, J. L., Kreidenweis, S. M., and Collett, J. L.: Photoacoustic and filter-based ambient aerosol light absorption measurements: instrument comparisons and the role of relative humidity, J. Geophys. Res., 108, 4034, https://doi.org/10.1029/2002JD002165, 2003.

Arnott, W. P., Hamasha, K., Moosmuller, H., Sheridan, P. J., and Ogren, J. A.: Towards aerosol light-absorption measurements with a 7-wavelength Aethalometer: evaluation with a photoacoustic instrument and 3-wavelength nephelometer, Aerosol Sci. Tech., 39, 17-29, https://doi.org/10.1080/027868290901972, 2005.

Bae, M. S., Schauer, J. J., DeMinter, J. T., Turner, J. R., Smith, D., and Cary, R. A.: Validation of a semi-continuous instrument for elemental carbon and organic carbon using a thermal-optical method, Atmos. Environ., 38, 2885-2893, https://doi.org/10.1016/j.atmosenv.2004.02.027, 2004.

Bauer, J. J., Yu, X.-Y., Cary, R., Laulainen, N., and Berkowitz, C.: Characterization of the sunset semi-continuous carbon aerosol analyzer, J. Air Waste Manage., 59, 826-833, https://doi.org/10.3155/1047-3289.59.7.826, 2009.

Bladt, H., Schmid, J., Kireeva, E. D., Popovicheva, O. B., Perseantseva, N. M., Timofeev, M. A., Heister, K., Uihlein, J., Ivleva, N. P., and Niessner, R.: Impact of Fe content in laboratory-produced soot aerosol on its composition, structure, and thermo-chemical properties, Aerosol Sci. Tech., 46, 13371348, https://doi.org/10.1080/02786826.2012.711917, 2012.

Bohren, C. F. and Huffman, D. R.: Absorption and Scattering of Light by Small Particles, xiv, Wiley, New York, USA, 530 pp., 1983.

Bond, T. C.: Spectral dependence of visible light absorption by carbonaceous particles emitted from coal combustion, Geophys. Res. Lett., 28, 4075-4078, https://doi.org/10.1029/2001g1013652, 2001.

Bond, T. C. and Bergstrom, R. W.: Light absorption by carbonaceous particles: an investigative review, Aerosol Sci. Tech., 40, 27-67, https://doi.org/10.1080/02786820500421521, 2006.

Bond, T. C., Habib, G., and Bergstrom, R. W.: Limitations in the enhancement of visible light absorption due to mixing state, J. Geophys. Res., 111, D20211, https://doi.org/10.1029/2006JD007315, 2006.

Bond, T. C., Zarzycki, C., Flanner, M. G., and Koch, D. M.: Quantifying immediate radiative forcing by black carbon and organic matter with the Specific Forcing Pulse, Atmos. Chem. Phys., 11, 1505-1525, https://doi.org/10.5194/acp-11-1505-2011, 2011.

Cappa, C. D., Lack, D. A., Burkholder, J. B., and Ravishankara, A. R.: Bias in filter-based aerosol light absorption measurements due to organic aerosol loading: evidence from laboratory measurements, Aerosol Sci. Tech., 42, 1022-1032, https://doi.org/10.1080/02786820802389285, 2008.

Cappa, C. D., Onasch, T. B., Massoli, P., Worsnop, D. R., Bates, T. S., Cross, E. S., Davidovits, P., Hakala, J., Hayden, K. L., Jobson, B. T., Kolesar, K. R., Lack, D. A., Lerner, B. M., Li, S.-M., Mellon, D., Nuaaman, I., Olfert, J. S., Petäjä, T., Quinn, P. K., Song, C., Subramanian, R., Williams, E. J., and Zaveri, R. A.: Radiative absorption enhancements due to the mixing state of atmospheric black carbon, Science, 337, 1078-1081, https://doi.org/10.1126/science.1223447, 2012.

Chan, T. W., Brook, J. R., Smallwood, G. J., and Lu, G.: Time-resolved measurements of black carbon light absorption enhancement in urban and near-urban locations of southern Ontario, Canada, Atmos. Chem. Phys., 11, 10407-10432, https://doi.org/10.5194/acp-11-10407-2011, 2011.

Chen, B., Bai, Z., Cui, X., Chen, J., Andersson, A., and Gustafsson, Ö.: Light absorption enhancement of black carbon from urban haze in Northern China winter, Environ. Pollut., 221, 418-426, https://doi.org/10.1016/j.envpol.2016.12.004, 2017.

Chen, Y. and Bond, T. C.: Light absorption by organic carbon from wood combustion, Atmos. Chem. Phys., 10, 1773-1787, https://doi.org/10.5194/acp-10-1773-2010, 2010.

Cheng, Y., He, K. B., Duan, F. K., Zheng, M., Ma, Y. L., and Tan, J. H.: Positive sampling artifact of carbonaceous aerosols and its influence on the thermal-optical split of OC / EC, Atmos. Chem. Phys., 9, 7243-7256, https://doi.org/10.5194/acp-9-7243-2009, 2009.

Cheng, Y., Engling, G., Moosmüller, H., Arnott, W. P., Chen, L. W. A., Wold, C. E., Hao, W. M., and He, K.-B.: Light absorption by biomass burning source emissions, Atmos. Environ., 127, 347-354, https://doi.org/10.1016/j.atmosenv.2015.12.045, 2016.

China, S., Mazzoleni, C., Gorkowski, K., Aiken, A. C., and Dubey, M. K.: Morphology and mixing state of individual freshly 
emitted wildfire carbonaceous particles, Nat. Commun., 4, 2122, https://doi.org/10.1038/ncomms3122, 2013.

Chow, J. C., Watson, J. G., Pritchett, L. C., Pierson, W. R., Frazier, C. A., and Purcell, R. G.: The DRI thermal/optical reflectance carbon analysis system: description, evaluation and applications in United-States air-quality studies, Atmos. Environ., 27, 1185-1201, https://doi.org/10.1016/0960-1686(93)90245-T, 1993.

Chow, J. C., Watson, J. G., Doraiswamy, P., Chen, L. W. A., Sodeman, D. A., Lowenthal, D. H., Park, K., Arnott, W. P., and Motallebi, N.: Aerosol light absorption, black carbon, and elemental carbon at the Fresno Supersite, California, Atmos. Res., 93, 874887, https://doi.org/10.1016/j.atmosres.2009.04.010, 2009.

Collaud Coen, M., Weingartner, E., Apituley, A., Ceburnis, D., Fierz-Schmidhauser, R., Flentje, H., Henzing, J. S., Jennings, S. G., Moerman, M., Petzold, A., Schmid, O., and Baltensperger, U.: Minimizing light absorption measurement artifacts of the Aethalometer: evaluation of five correction algorithms, Atmos. Meas. Tech., 3, 457-474, https://doi.org/10.5194/amt-3-4572010, 2010.

Cui, F., Chen, M., Ma, Y., Zheng, J., Zhou, Y., Li, S., Qi, L., and Wang, L.: An intensive study on aerosol optical properties and affecting factors in Nanjing, China, J. Environ. Sci., 40, 35-43, https://doi.org/10.1016/j.jes.2015.08.017, 2016.

Cui, X., Wang, X., Yang, L., Chen, B., Chen, J., Andersson, A., and Gustafsson, Ö.: Radiative absorption enhancement from coatings on black carbon aerosols, Sci. Total Environ., 551, 51-56, https://doi.org/10.1016/j.scitotenv.2016.02.026, 2016.

Dastanpour, R., Momenimovahed, A., Thomson, K., Olfert, J., and Rogak, S.: Variation of the optical properties of soot as a function of particle mass, Carbon, 124, 201-211, https://doi.org/10.1016/j.carbon.2017.07.005, 2017.

Ding, A. J., Huang, X., Nie, W., Sun, J. N., Kerminen, V. M., Petäjä, T., Su, H., Cheng, Y. F., Yang, X. Q., Wang, M. H., Chi, X. G., Wang, J. P., Virkkula, A., Guo, W. D., Yuan, J., Wang, S. Y., Zhang, R. J., Wu, Y. F., Song, Y., Zhu, T., Zilitinkevich, S., Kulmala, M., and Fu, C. B.: Enhanced haze pollution by black carbon in megacities in China, Geophys. Res. Lett., 43, 2873-2879, https://doi.org/10.1002/2016GL067745, 2016.

Doran, J. C., Barnard, J. C., Arnott, W. P., Cary, R., Coulter, R., Fast, J. D., Kassianov, E. I., Kleinman, L., Laulainen, N. S., Martin, T., Paredes-Miranda, G., Pekour, M. S., Shaw, W. J., Smith, D. F., Springston, S. R., and Yu, X.-Y.: The T1-T2 study: evolution of aerosol properties downwind of Mexico City, Atmos. Chem. Phys., 7, 1585-1598, https://doi.org/10.5194/acp-7-15852007, 2007.

Draxier, R. R. and Hess, G. D.: An overview of the HYSPLIT_4 modelling system for trajectories, dispersion and deposition, Aust. Meteorol. Mag., 47, 295-308, 1998.

Drinovec, L., Gregorič, A., Zotter, P., Wolf, R., Bruns, E. A., Prévôt, A. S. H., Petit, J.-E., Favez, O., Sciare, J., Arnold, I. J., Chakrabarty, R. K., Moosmüller, H., Filep, A., and Močnik, G.: The filter-loading effect by ambient aerosols in filter absorption photometers depends on the coating of the sampled particles, Atmos. Meas. Tech., 10, 1043-1059, https://doi.org/10.5194/amt10-1043-2017, 2017.

Fialho, P., Hansen, A. D. A., and Honrath, R. E.: Absorption coefficients by aerosols in remote areas: a new approach to decouple dust and black carbon absorption coefficients using seven- wavelength Aethalometer data, J. Aerosol Sci., 36, 267-282, https://doi.org/10.1016/j.jaerosci.2004.09.004, 2005.

Fuller, K. A., Malm, W. C., and Kreidenweis, S. M.: Effects of mixing on extinction by carbonaceous particles, J. Geophys. Res., 104, 15941-15954, 1999.

Gong, X., Zhang, C., Chen, H., Nizkorodov, S. A., Chen, J., and Yang, X.: Size distribution and mixing state of black carbon particles during a heavy air pollution episode in Shanghai, Atmos. Chem. Phys., 16, 5399-5411, https://doi.org/10.5194/acp16-5399-2016, 2016.

Guo, S., Hu, M., Lin, Y., Gomez-Hernandez, M., Zamora, M. L., Peng, J., Collins, D. R., and Zhang, R.: OH-initiated oxidation of m-Xylene on Black Carbon aging, Environ. Sci. Technol., 50, 8605-8612, https://doi.org/10.1021/acs.est.6b01272, 2016.

Guyon, P., Graham, B., Roberts, G. C., Mayol-Bracero, O. L., Maenhaut, W., Artaxo, P., and Andreae, M. O.: Sources of optically active aerosol particles over the Amazon forest, Atmos. Environ., 38, 1039-1051, https://doi.org/10.1016/j.atmosenv.2003.10.051, 2004.

Hansen, A. D. A.: The Aethalometer Manual, Magee Scientific, Berkeley, California, USA, 2005.

Hansen, J. and Nazarenko, L.: Soot climate forcing via snow and ice albedos, P. Natl. Acad. Sci. USA, 101, 423-428, https://doi.org/10.1073/pnas.2237157100, 2004.

Healy, R. M., Wang, J. M., Jeong, C. H., Lee, A. K. Y., Willis, M. D., Jaroudi, E., Zimmerman, N., Hilker, N., Murphy, M., Eckhardt, S., Stohl, A., Abbatt, J. P. D., Wenger, J. C., and Evans, G. J.: Light-absorbing properties of ambient black carbon and brown carbon from fossil fuel and biomass burning sources, J. Geophys. Res., 120, 2015JD023382, https://doi.org/10.1002/2015JD023382, 2015.

Herich, H., Hueglin, C., and Buchmann, B.: A 2.5 year's source apportionment study of black carbon from wood burning and fossil fuel combustion at urban and rural sites in Switzerland, Atmos. Meas. Tech., 4, 1409-1420, https://doi.org/10.5194/amt-4-14092011, 2011.

Hoffer, A., Gelencsér, A., Guyon, P., Kiss, G., Schmid, O., Frank, G. P., Artaxo, P., and Andreae, M. O.: Optical properties of humiclike substances (HULIS) in biomass-burning aerosols, Atmos. Chem. Phys., 6, 3563-3570, https://doi.org/10.5194/acp-6-35632006, 2006.

Huang, X.-F., He, L.-Y., Hu, M., Canagaratna, M. R., Kroll, J. H., Ng, N. L., Zhang, Y.-H., Lin, Y., Xue, L., Sun, T.L., Liu, X.-G., Shao, M., Jayne, J. T., and Worsnop, D. R.: Characterization of submicron aerosols at a rural site in Pearl River Delta of China using an Aerodyne High-Resolution Aerosol Mass Spectrometer, Atmos. Chem. Phys., 11, 18651877, https://doi.org/10.5194/acp-11-1865-2011, 2011.

IPCC: Climate change 2013: The Physical Science Basis: Working Group I Contribution to the Fifth Assessment Report of the Intergovernmental Panel on Climate Change, xi, editec by: Stocker, T., Cambridge University Press, Cambridge, UK, 1535 pp., 2013.

Jacobson, M. Z.: Effects of externally-through-internallymixed soot inclusions within clouds and precipitation on global climate, J. Phys. Chem. A, 110, 6860-6873, https://doi.org/10.1021/jp056391r, 2006.

Jason Blake, C.: Quantifying the occurrence and magnitude of the Southeast Asian fire climatology, Environ. Res. Lett., 9, 114018, 2014. 
Jung, J., Lee, H., Kim, Y. J., Liu, X., Zhang, Y., Gu, J., and Fan, S.: Aerosol chemistry and the effect of aerosol water content on visibility impairment and radiative forcing in Guangzhou during the 2006 Pearl River Delta campaign, J. Environ. Manage., 90, 3231-3244, https://doi.org/10.1016/j.jenvman.2009.04.021, 2009.

Khalizov, A. F., Xue, H. X., Wang, L., Zheng, J., and Zhang, R. Y.: Enhanced Light Absorption and Scattering by Carbon Soot Aerosol Internally Mixed with Sulfuric Acid, J. Phys. Chem. A, 113, 1066-1074, https://doi.org/10.1021/jp807531n, 2009.

Kirchstetter, T. W., Novakov, T., and Hobbs, P. V.: Evidence that the spectral dependence of light absorption by aerosols is affected by organic carbon, J. Geophys. Res., 109, D21208, https://doi.org/10.1029/2004jd004999, 2004.

Knox, A., Evans, G. J., Brook, J. R., Yao, X., Jeong, C. H., Godri, K. J., Sabaliauskas, K., and Slowik, J. G.: Mass absorption cross-section of ambient Black Carbon aerosol in relation to chemical age, Aerosol Sci. Tech., 43, 522-532, https://doi.org/10.1080/02786820902777207, 2009.

Koch, D. and Del Genio, A. D.: Black carbon semi-direct effects on cloud cover: review and synthesis, Atmos. Chem. Phys., 10, 7685-7696, https://doi.org/10.5194/acp-10-7685-2010, 2010.

Kozlov, V. S., Panchenko, M. V., Tikhomirov, A. B., Tikhomirov, B. A., and Shmargunov, V. P.: Effect of relative air humidity on photoacoustic aerosol absorption measurements in the near-ground atmospheric layer, Atmospheric and Oceanic Optics, 24, 487, https://doi.org/10.1134/s1024856011050101, 2011.

Laborde, M., Mertes, P., Zieger, P., Dommen, J., Baltensperger, U., and Gysel, M.: Sensitivity of the Single Particle Soot Photometer to different black carbon types, Atmos. Meas. Tech., 5, 10311043, https://doi.org/10.5194/amt-5-1031-2012, 2012.

Lack, D. A. and Cappa, C. D.: Impact of brown and clear carbon on light absorption enhancement, single scatter albedo and absorption wavelength dependence of black carbon, Atmos. Chem. Phys., 10, 4207-4220, https://doi.org/10.5194/acp10-4207-2010, 2010.

Lack, D. A. and Langridge, J. M.: On the attribution of black and brown carbon light absorption using the Ångström exponent, Atmos. Chem. Phys., 13, 10535-10543, https://doi.org/10.5194/acp-13-10535-2013, 2013.

Lack, D. A., Langridge, J. M., Bahreini, R., Cappa, C. D., Middlebrook, A. M., and Schwarz, J. P.: Brown carbon and internal mixing in biomass burning particles, P. Natl. Acad. Sci. USA, 109, 14802-14807, https://doi.org/10.1073/pnas.1206575109, 2012a.

Lack, D. A., Richardson, M. S., Law, D., Langridge, J. M., Cappa, C. D., McLaughlin, R. J., and Murphy, D. M.: Aircraft instrument for comprehensive characterization of aerosol optical properties, Part 2: black and brown carbon absorption and absorption enhancement measured with photo acoustic spectroscopy, Aerosol Sci. Tech., 46, 555-568, https://doi.org/10.1080/02786826.2011.645955, 2012b.

Lan, Z.-J., Huang, X.-F., Yu, K.-Y., Sun, T.-L., Zeng, L.W., and $\mathrm{Hu}, \mathrm{M}$. : Light absorption of black carbon aerosol and its enhancement by mixing state in an urban atmosphere in South China, Atmos. Environ., 69, 118-123, https://doi.org/10.1016/j.atmosenv.2012.12.009, 2013.

Langridge, J. M., Richardson, M. S., Lack, D. A., Brock, C. A., and Murphy, D. M.: Limitations of the photoacoustic technique for aerosol absorption measurement at high relative humidity, Aerosol Sci. Tech., 47, 1163-1173, https://doi.org/10.1080/02786826.2013.827324, 2013.

Lee, H. M., Okuyama, K., Mizohata, A., Kim, T. O., and Koyama, H.: Fabrication of reference filter for measurements of EC (elemental carbon) and OC (organic carbon) in aerosol particles, Aerosol Sci. Tech., 41, 284-294, https://doi.org/10.1080/02786820701197060, 2007.

Leung, K. K., Schnitzler, E. G., Jäger, W., and Olfert, J. S.: Relative Humidity Dependence of Soot Aggregate Restructuring Induced by Secondary Organic Aerosol: effects of Water on Coating Viscosity and Surface Tension, Environ. Sci. Tech. Let., 4, 386-390, https://doi.org/10.1021/acs.estlett.7b00298, 2017.

Lewis, K. A., Arnott, W. P., Moosmüller, H., Chakrabarty, R. K., Carrico, C. M., Kreidenweis, S. M., Day, D. E., Malm, W. C., Laskin, A., Jimenez, J. L., Ulbrich, I. M., Huffman, J. A., Onasch, T. B., Trimborn, A., Liu, L., and Mishchenko, M. I.: Reduction in biomass burning aerosol light absorption upon humidification: roles of inorganically-induced hygroscopicity, particle collapse, and photoacoustic heat and mass transfer, Atmos. Chem. Phys., 9, 8949-8966, https://doi.org/10.5194/acp-9-89492009, 2009a.

Lewis, K. A., Arnott, W. P., Moosmüller, H., Chakrabarty, R. K., Carrico, C. M., Kreidenweis, S. M., Day, D. E., Malm, W. C., Laskin, A., Jimenez, J. L., Ulbrich, I. M., Huffman, J. A., Onasch, T. B., Trimborn, A., Liu, L., and Mishchenko, M. I.: Reduction in biomass burning aerosol light absorption upon humidification: roles of inorganically-induced hygroscopicity, particle collapse, and photoacoustic heat and mass transfer, Atmos. Chem. Phys., 9, 8949-8966, https://doi.org/10.5194/acp-9-89492009, 2009b.

Lin, P., Aiona, P. K., Li, Y., Shiraiwa, M., Laskin, J., Nizkorodov, S. A., and Laskin, A.: Molecular characterization of brown carbon in biomass burning aerosol particles, Environ. Sci. Technol., 50, 11815-11824, https://doi.org/10.1021/acs.est.6b03024, 2016.

Liu, D., Whitehead, J., Alfarra, M. R., Reyes-Villegas, E., Spracklen, D. V., Reddington, C. L., Kong, S., Williams, P. I., Ting, Y.-C., Haslett, S., Taylor, J. W., Flynn, M. J., Morgan, W. T., McFiggans, G., Coe, H., and Allan, J. D.: Black-carbon absorption enhancement in the atmosphere determined by particle mixing state, Nat. Geosci., 10, 184-188, https://doi.org/10.1038/ngeo2901, 2017.

Liu, F., Yon, J., and Bescond, A.: On the radiative properties of soot aggregates - Part 2: Effects of coating, J. Quant. Spectrosc. Ra., 172, 134-145, https://doi.org/10.1016/j.jqsrt.2015.08.005, 2016.

Liu, J., Lin, P., Laskin, A., Laskin, J., Kathmann, S. M., Wise, M., Caylor, R., Imholt, F., Selimovic, V., and Shilling, J. E.: Optical properties and aging of light-absorbing secondary organic aerosol, Atmos. Chem. Phys., 16, 12815-12827, https://doi.org/10.5194/acp-16-12815-2016, 2016.

Liu, S., Aiken, A. C., Gorkowski, K., Dubey, M. K., Cappa, C. D., Williams, L. R., Herndon, S. C., Massoli, P., Fortner, E. C., Chhabra, P. S., Brooks, W. A., Onasch, T. B., Jayne, J. T., Worsnop, D. R., China, S., Sharma, N., Mazzoleni, C., Xu, L., Ng, N. L., Liu, D., Allan, J. D., Lee, J. D., Fleming, Z. L., Mohr, C., Zotter, P., Szidat, S., and Prevot, A. S. H.: Enhanced light absorption by mixed source black and brown 
carbon particles in UK winter, Nat. Commun., 6, 8435, https://doi.org/10.1038/ncomms9435, 2015.

Ma, N., Zhao, C. S., Müller, T., Cheng, Y. F., Liu, P. F., Deng, Z. Z., Xu, W. Y., Ran, L., Nekat, B., van Pinxteren, D., Gnauk, T., Müller, K., Herrmann, H., Yan, P., Zhou, X. J., and Wiedensohler, A.: A new method to determine the mixing state of light absorbing carbonaceous using the measured aerosol optical properties and number size distributions, Atmos. Chem. Phys., 12, 23812397, https://doi.org/10.5194/acp-12-2381-2012, 2012.

Magee Scientific: Replacement Filter Tape for the Magee Scientific Model AE33 Aethalometer ${ }^{\circledR}$, available at: http: //www.mageesci.com/images/stories/docs/Magee_Scientific_ Filter_Aethalometer_AE_Tape_Replacement_discussion.pdf (10 January 2018), 2017.

Matsui, H., Koike, M., Kondo, Y., Moteki, N., Fast, J. D., and Zaveri, R. A.: Development and validation of a black carbon mixing state resolved three-dimensional model: aging processes and radiative impact, J. Geophys. Res., 118, 2304-2326, https://doi.org/10.1029/2012JD018446, 2013.

McMeeking, G. R., Fortner, E., Onasch, T. B., Taylor, J. W., Flynn, M., Coe, H., and Kreidenweis, S. M.: Impacts of nonrefractory material on light absorption by aerosols emitted from biomass burning, J. Geophys. Res., 119, 12272-12286, https://doi.org/10.1002/2014JD021750, 2014.

Moffet, R. C., O'Brien, R. E., Alpert, P. A., Kelly, S. T., Pham, D. Q., Gilles, M. K., Knopf, D. A., and Laskin, A.: Morphology and mixing of black carbon particles collected in central California during the CARES field study, Atmos. Chem. Phys., 16, 1451514525, https://doi.org/10.5194/acp-16-14515-2016, 2016.

Moosmüller, H., Chakrabarty, R. K., Ehlers, K. M., and Arnott, W. P.: Absorption Ångström coefficient, brown carbon, and aerosols: basic concepts, bulk matter, and spherical particles, Atmos. Chem. Phys., 11, 1217-1225, https://doi.org/10.5194/acp11-1217-2011, 2011.

Moteki, N., Kondo, Y., and Adachi, K.: Identification by singleparticle soot photometer of black carbon particles attached to other particles: laboratory experiments and ground observations in Tokyo, J. Geophys. Res., 119, 1031-1043, https://doi.org/10.1002/2013jd020655, 2014

Nakayama, T., Ikeda, Y., Sawada, Y., Setoguchi, Y., Ogawa, S., Kawana, K., Mochida, M., Ikemori, F., Matsumoto, K., and Matsumi, Y.: Properties of light-absorbing aerosols in the Nagoya urban area, Japan, in August 2011 and January 2012: Contributions of brown carbon and lensing effect, J. Geophys. Res., 119, 12721-12739, https://doi.org/10.1002/2014JD021744, 2014.

Naoe, H., Hasegawa, S., Heintzenberg, J., Okada, K., Uchiyama, A., Zaizen, Y., Kobayashi, E., and Yamazaki, A.: State of mixture of atmospheric submicrometer black carbon particles and its effect on particulate light absorption, Atmos. Environ., 43, 1296-1301, https://doi.org/10.1016/j.atmosenv.2008.11.031, 2009.

Nordmann, S., Cheng, Y. F., Carmichael, G. R., Yu, M., Denier van der Gon, H. A. C., Zhang, Q., Saide, P. E., Pöschl, U., Su, H., Birmili, W., and Wiedensohler, A.: Atmospheric black carbon and warming effects influenced by the source and absorption enhancement in central Europe, Atmos. Chem. Phys., 14, 1268312699, https://doi.org/10.5194/acp-14-12683-2014, 2014.

Pandey, A., Pervez, S., and Chakrabarty, R. K.: Filter-based measurements of UV-vis mass absorption cross sections of organic carbon aerosol from residential biomass combustion: preliminary findings and sources of uncertainty, J. Quant. Spectrosc. Ra., 182, 296-304, https://doi.org/10.1016/j.jqsrt.2016.06.023, 2016.

Pei, X., Hallquist, M., Eriksson, A. C., Pagels, J. H., Donahue, N. M., Mentel, T., Svenningsson, B., Brune, W., and Pathak, R. K.: Morphological transformation of soot: investigation of microphysical processes during the condensation of sulfuric acid and limonene ozonolysis product vapors, Atmos. Chem. Phys. Discuss., https://doi.org/10.5194/acp-2017-769, in review, 2017.

Peng, J., Hu, M., Guo, S., Du, Z., Zheng, J., Shang, D., Levy Zamora, M., Zeng, L., Shao, M., Wu, Y.-S., Zheng, J., Wang, Y., Glen, C. R., Collins, D. R., Molina, M. J., and Zhang, R.: Markedly enhanced absorption and direct radiative forcing of black carbon under polluted urban environments, P. Natl. Acad. Sci. USA, 113, 4266-4271, https://doi.org/10.1073/pnas.1602310113, 2016.

Pokhrel, R. P., Beamesderfer, E. R., Wagner, N. L., Langridge, J. M., Lack, D. A., Jayarathne, T., Stone, E. A., Stockwell, C. E., Yokelson, R. J., and Murphy, S. M.: Relative importance of black carbon, brown carbon, and absorption enhancement from clear coatings in biomass burning emissions, Atmos. Chem. Phys., 17, 5063-5078, https://doi.org/10.5194/acp-17-5063-2017, 2017.

Ramanathan, V. and Carmichael, G.: Global and regional climate changes due to black carbon, Nat. Geosci., 1, 221-227, https://doi.org/10.1038/Ngeo156, 2008.

Raspet, R., Slaton, W. V., Arnott, W. P., and Moosmüller, H.: Evaporation-Condensation Effects on Resonant Photoacoustics of Volatile Aerosols, J. Atmos. Ocean. Tech., 20, 685-695, https://doi.org/10.1175/15200426(2003)20<685:eceorp>2.0.co;2, 2003.

Reid, J. S., Eck, T. F., Christopher, S. A., Koppmann, R., Dubovik, O., Eleuterio, D. P., Holben, B. N., Reid, E. A., and Zhang, J.: A review of biomass burning emissions part III: intensive optical properties of biomass burning particles, Atmos. Chem. Phys., 5, 827-849, https://doi.org/10.5194/acp-5-827-2005, 2005.

Roden, C. A., Bond, T. C., Conway, S., and Pinel, A. B. O.: Emission factors and real-time optical properties of particles emitted from traditional wood burning cookstoves, Environ. Sci. Technol., 40, 6750-6757, https://doi.org/10.1021/es052080i, 2006.

Rose, D., Wehner, B., Ketzel, M., Engler, C., Voigtländer, J., Tuch, T., and Wiedensohler, A.: Atmospheric number size distributions of soot particles and estimation of emission factors, Atmos. Chem. Phys., 6, 1021-1031, https://doi.org/10.5194/acp-6-10212006, 2006.

Saathoff, H., Naumann, K. H., Schnaiter, M., Schöck, W., Möhler, O., Schurath, U., Weingartner, E., Gysel, M., and Baltensperger, U.: Coating of soot and $\left(\mathrm{NH}_{4}\right)_{2} \mathrm{SO}_{4}$ particles by ozonolysis products of $\alpha$-pinene, J. Aerosol. Sci., 34, 12971321, https://doi.org/10.1016/S0021-8502(03)00364-1, 2003.

Sandradewi, J., Prévôt, A. S. H., Weingartner, E., Schmidhauser, R., Gysel, M., and Baltensperger, U.: A study of wood burning and traffic aerosols in an Alpine valley using a multi-wavelength Aethalometer, Atmos. Environ., 42, 101112, https://doi.org/10.1016/j.atmosenv.2007.09.034, 2008.

Saturno, J., Pöhlker, C., Massabò, D., Brito, J., Carbone, S., Cheng, Y., Chi, X., Ditas, F., Hrabě de Angelis, I., Morán-Zuloaga, D., Pöhlker, M. L., Rizzo, L. V., Walter, D., Wang, Q., Artaxo, P., Prati, P., and Andreae, M. O.: Comparison of different Aethalometer correction schemes and a reference multiwavelength absorption technique for ambient aerosol data, At- 
mos. Meas. Tech., 10, 2837-2850, https://doi.org/10.5194/amt10-2837-2017, 2017.

Schmid, O., Artaxo, P., Arnott, W. P., Chand, D., Gatti, L. V., Frank, G. P., Hoffer, A., Schnaiter, M., and Andreae, M. O.: Spectral light absorption by ambient aerosols influenced by biomass burning in the Amazon Basin. I: Comparison and field calibration of absorption measurement techniques, Atmos. Chem. Phys., 6, 3443-3462, https://doi.org/10.5194/acp-6-3443-2006, 2006.

Schnaiter, M., Linke, C., Mohler, O., Naumann, K. H., Saathoff, H., Wagner, R., Schurath, U., and Wehner, B.: Absorption amplification of black carbon internally mixed with secondary organic aerosol, J. Geophys. Res., 110, D19204, https://doi.org/10.1029/2005JD006046, 2005.

Schwarz, J. P., Spackman, J. R., Fahey, D. W., Gao, R. S., Lohmann, U., Stier, P., Watts, L. A., Thomson, D. S., Lack, D. A., Pfister, L., Mahoney, M. J., Baumgardner, D., Wilson, J. C., and Reeves, J. M.: Coatings and their enhancement of black carbon light absorption in the tropical atmosphere, J. Geophys. Res., 113, D03203, https://doi.org/10.1029/2007JD009042, 2008.

Sedlacek, A. J., Lewis, E. R., Kleinman, L., Xu, J. Z., and Zhang, Q.: Determination of and evidence for non-core-shell structure of particles containing black carbon using the singleparticle Soot Photometer (SP2), Geophys. Res. Lett., 39, L06802, https://doi.org/10.1029/2012GL050905, 2012.

Shen, G., Chen, Y., Wei, S., Fu, X., Zhu, Y., and Tao, S.: Mass absorption efficiency of elemental carbon for source samples from residential biomass and coal combustions, Atmos. Environ., 79, 79-84, https://doi.org/10.1016/j.atmosenv.2013.05.082, 2013.

Shiraiwa, M., Kondo, Y., Iwamoto, T., and Kita, K.: Amplification of Light Absorption of Black Carbon by Organic Coating, Aerosol Sci. Tech., 44, 46-54, https://doi.org/10.1080/02786820903357686, 2010.

Subramanian, R., Khlystov, A. Y., Cabada, J. C., and Robinson, A. L.: Positive and negative artifacts in particulate organic carbon measurements with denuded and undenuded sampler configurations, Aerosol Sci. Tech., 38, 27-48, https://doi.org/10.1080/02786820390229354, 2004.

Suglia, S. F., Gryparis, A., Wright, R. O., Schwartz, J., and Wright, R. J.: Association of Black Carbon with Cognition among Children in a Prospective Birth Cohort Study, Am. J. Epidemiol., 167, 280-286, https://doi.org/10.1093/aje/kwm308, 2008.

Tan, H., Liu, L., Fan, S., Li, F., Yin, Y., Cai, M., and Chan, P. W.: Aerosol optical properties and mixing state of black carbon in the Pearl River Delta, China, Atmos. Environ., 131, 196-208, https://doi.org/10.1016/j.atmosenv.2016.02.003, 2016.

Tao, W. K., Chen, J. P., Li, Z. Q., Wang, C., and Zhang, C. D.: Impact of aerosols on convective clouds and precipitation, Rev. Geophys., 50, Rg2001, https://doi.org/10.1029/2011rg000369, 2012.

Tasoglou, A., Saliba, G., Subramanian, R., and Pandis, S. N.: Absorption of chemically aged biomass burning carbonaceous aerosol, J. Aerosol Sci., 113, 141-152, https://doi.org/10.1016/j.jaerosci.2017.07.011, 2017.

Tavakoli, F. and Olfert, J. S.: Determination of particle mass, effective density, mass-mobility exponent, and dynamic shape factor using an aerodynamic aerosol classifier and a differential mobility analyzer in tandem, J. Aerosol Sci., 75, 35-42, https://doi.org/10.1016/j.jaerosci.2014.04.010, 2014. ten Brink, H., Otjes, R., Jongejan, P., and Slanina, S.: An instrument for semi-continuous monitoring of the size-distribution of nitrate, ammonium, sulphate and chloride in aerosol, Atmos. Environ., 41, 2768-2779, https://doi.org/10.1016/j.atmosenv.2006.11.041, 2007.

Turpin, B. J. and Huntzicker, J. J.: Secondary formation of organic aerosol in the Los-Angeles Basin - a descriptive analysis of organic and elemental carbon concentrations, Atmos. Environ., 25, 207-215, https://doi.org/10.1016/0960-1686(91)90291-E, 1991.

Ueda, S., Nakayama, T., Taketani, F., Adachi, K., Matsuki, A., Iwamoto, Y., Sadanaga, Y., and Matsumi, Y.: Light absorption and morphological properties of soot-containing aerosols observed at an East Asian outflow site, Noto Peninsula, Japan, Atmos. Chem. Phys., 16, 2525-2541, https://doi.org/10.5194/acp16-2525-2016, 2016.

Virkkula, A., Makela, T., Hillamo, R., Yli-Tuomi, T., Hirsikko, A., Hameri, K., and Koponen, I. K.: A simple procedure for correcting loading effects of aethalometer data, Japca. J. Air Waste Ma., 57, 1214-1222, https://doi.org/10.3155/1047-3289.57.10.1214, 2007.

Wang, Q., Huang, R., Zhao, Z., Cao, J., Ni, H., Tie, X., Zhu, C., Shen, Z., Wang, M., and Dai, W.: Effects of photochemical oxidation on the mixing state and light absorption of black carbon in the urban atmosphere of China, Environ. Res. Lett., 12, 044012, https://doi.org/10.1088/1748-9326/aa64ea, 2017.

Wang, Q. Y., Huang, R. J., Cao, J. J., Han, Y. M., Wang, G. H., Li, G. H., Wang, Y. C., Dai, W. T., Zhang, R. J., and Zhou, Y. Q.: Mixing State of Black Carbon Aerosol in a Heavily Polluted Urban Area of China: implications for Light Absorption Enhancement, Aerosol Sci. Tech., 48, 689-697, https://doi.org/10.1080/02786826.2014.917758, 2014.

Wang, Y., Chung, A., and Paulson, S. E.: The effect of metal salts on quantification of elemental and organic carbon in diesel exhaust particles using thermal-optical evolved gas analysis, Atmos. Chem. Phys., 10, 11447-11457, https://doi.org/10.5194/acp-1011447-2010, 2010.

Wang, Y. Q.: MeteoInfo: GIS software for meteorological data visualization and analysis, Meteorol. Appl., 21, 360-368, https://doi.org/10.1002/met.1345, 2014.

Weingartner, E., Saathoff, H., Schnaiter, M., Streit, N., Bitnar, B., and Baltensperger, U.: Absorption of light by soot particles: determination of the absorption coefficient by means of aethalometers, J. Aerosol Sci., 34, 1445-1463, https://doi.org/10.1016/S0021-8502(03)00359-8, 2003.

Weyant, C. L., Shepson, P. B., Subramanian, R., Cambaliza, M. O. L., Heimburger, A., McCabe, D., Baum, E., Stirm, B. H., and Bond, T. C.: Black carbon emissions from associated natural gas flaring, Environ. Sci. Technol., 50, 2075-2081, https://doi.org/10.1021/acs.est.5b04712, 2016.

Wild, M.: Enlightening global dimming and brightening, B. Am. Meteorol. Soc., 93, 27-37, https://doi.org/10.1175/bams-d-1100074.1, 2011.

Wu, C.: Aethalometer data processor, https://doi.org/10.5281/zenodo.832404, 2017a.

Wu, C.: Minimum R Square Method (MRS), https://doi.org/10.5281/zenodo.832396, $2017 \mathrm{~b}$.

Wu, C.: Histbox, https://doi.org/10.5281/zenodo.832411, $2017 \mathrm{c}$.

Wu, C.: Scatter Plot, https://doi.org/10.5281/zenodo.832417, 2017d. 
Wu, C.: Mie Scattering, https://doi.org/10.5281/zenodo.832400, 2017e.

Wu, C. and Yu, J. Z.: Determination of primary combustion source organic carbon-to-elemental carbon (OC/EC) ratio using ambient OC and EC measurements: secondary OC-EC correlation minimization method, Atmos. Chem. Phys., 16, 5453-5465, https://doi.org/10.5194/acp-16-5453-2016, 2016.

Wu, C., Ng, W. M., Huang, J., Wu, D., and Yu, J. Z.: Determination of elemental and organic carbon in $\mathrm{PM}_{2.5}$ in the Pearl River Delta Region: Inter-instrument (Sunset vs. DRI Model 2001 Thermal/Optical Carbon Analyzer) and Inter-Protocol Comparisons (IMPROVE vs. ACE-Asia Protocol), Aerosol Sci. Tech., 46, 610-621, https://doi.org/10.1080/02786826.2011.649313, 2012.

Wu, C., Huang, X. H. H., Ng, W. M., Griffith, S. M., and $\mathrm{Yu}, \mathrm{J}$. Z.: Inter-comparison of NIOSH and IMPROVE protocols for OC and EC determination: implications for interprotocol data conversion, Atmos. Meas. Tech., 9, 4547-4560, https://doi.org/10.5194/amt-9-4547-2016, 2016.

Wu, D., Mao, J. T., Deng, X. J., Tie, X. X., Zhang, Y. H., Zeng, L. M., Li, F., Tan, H. B., Bi, X. Y., Huang, X. Y., Chen, J., and Deng, T.: Black carbon aerosols and their radiative properties in the Pearl River Delta region, Sci. China Ser. D, 52, 1152-1163, https://doi.org/10.1007/s11430-009-0115-y, 2009.

Wu, D., Wu, C., Liao, B., Chen, H., Wu, M., Li, F., Tan, H., Deng, T., Li, H., Jiang, D., and Yu, J. Z.: Black carbon over the South China Sea and in various continental locations in South China, Atmos. Chem. Phys., 13, 12257-12270, https://doi.org/10.5194/acp-13-12257-2013, 2013.

Wu, Y., Zhang, R., Tian, P., Tao, J., Hsu, S. C., Yan, P., Wang, Q., Cao, J., Zhang, X., and Xia, X.: Effect of ambient humidity on the light absorption amplification of black carbon in Beijing during January 2013, Atmos. Environ. B-Urb., 124, 217-223, https://doi.org/10.1016/j.atmosenv.2015.04.041, 2016.
Yang, M., Howell, S. G., Zhuang, J., and Huebert, B. J.: Attribution of aerosol light absorption to black carbon, brown carbon, and dust in China - interpretations of atmospheric measurements during EAST-AIRE, Atmos. Chem. Phys., 9, 2035-2050, https://doi.org/10.5194/acp-9-2035-2009, 2009.

Yu, H., Wu, C., Wu, D., and Yu, J. Z.: Size distributions of elemental carbon and its contribution to light extinction in urban and rural locations in the pearl river delta region, China, Atmos. Chem. Phys., 10, 5107-5119, https://doi.org/10.5194/acp10-5107-2010, 2010.

Yuan, J.-F., Huang, X.-F., Cao, L.-M., Cui, J., Zhu, Q., Huang, C.N., Lan, Z.-J., and He, L.-Y.: Light absorption of brown carbon aerosol in the PRD region of China, Atmos. Chem. Phys., 16, 1433-1443, https://doi.org/10.5194/acp-16-1433-2016, 2016.

Zhang, G., Bi, X., Qiu, N., Han, B., Lin, Q., Peng, L., Chen, D., Wang, X., Peng, P., Sheng, G., and Zhou, Z.: The real part of the refractive indices and effective densities for chemically segregated ambient aerosols in Guangzhou measured by a singleparticle aerosol mass spectrometer, Atmos. Chem. Phys., 16, 2631-2640, https://doi.org/10.5194/acp-16-2631-2016, 2016.

Zhang, R. Y., Khalizov, A. F., Pagels, J., Zhang, D., Xue, H. X., and McMurry, P. H.: Variability in morphology, hygroscopicity, and optical properties of soot aerosols during atmospheric processing, P. Natl. Acad. Sci. USA, 105, 10291-10296, https://doi.org/10.1073/pnas.0804860105, 2008.

Zhang, Y., Zhang, Q., Cheng, Y., Su, H., Kecorius, S., Wang, Z., Wu, Z., Hu, M., Zhu, T., Wiedensohler, A., and He, K.: Measuring the morphology and density of internally mixed black carbon with SP2 and VTDMA: new insight into the absorption enhancement of black carbon in the atmosphere, Atmos. Meas. Tech., 9, 1833-1843, https://doi.org/10.5194/amt-9-1833-2016, 2016. 